Article

\title{
Photophysicochemical Properties and In Vitro Phototherapeutic Effects of Iodoquinoline- and Benzothiazole-Derived Unsymmetrical Squaraine Cyanine Dyes
}

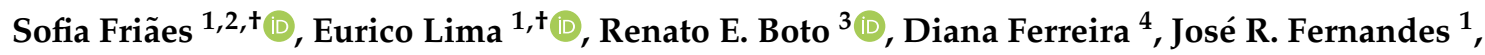 \\ Luis F. V. Ferreira ${ }^{4}\left(\mathbb{D}\right.$, Amélia M. Silva ${ }^{2, *} *^{-1}$ and Lucinda V. Reis $1, * \mathbb{C}$ \\ 1 Chemistry Centre of Vila Real (CQ-VR), University of Trás-os-Montes and Alto Douro, Quinta de Prados, \\ 5001-801 Vila Real, Portugal; sofia_friaes@hotmail.com (S.F.); eurico_lima@icloud.com (E.L.); \\ jraf@utad.pt (J.R.F.) \\ 2 Centre for Research and Technology of Agro-Environmental and Biological Sciences (CITAB-UTAD), \\ University of Trás-os-Montes and Alto Douro, Quinta de Prados, 5001-801 Vila Real, Portugal \\ 3 Health Sciences Research Centre (CICS-UBI), University of Beira Interior, Av. Infante D. Henrique, \\ 6201-001 Covilhã, Portugal; rboto@ubi.pt \\ 4 Centro de Química-Física Molecular (CQFM), Institute for Nanosciences and Nanotechnology (IN) and \\ Institute of Bioengineering and Biosciences (iBB), Higher Technical Institute, University of Lisbon, Av. \\ Rovisco Pais, 1049-001 Lisbon, Portugal; diana.ferreira@ist.utl.pt (D.F.); luisfilipevf@ist.utl.pt (L.F.V.F.) \\ * Correspondence: amsilva@utad.pt (A.M.S.); lucinda.reis@utad.pt (L.V.R.) \\ $\dagger$ Both authors can be considered first author since they contributed equally to this work.
}

Received: 25 November 2019; Accepted: 9 December 2019; Published: 11 December 2019

Featured Application: Potential application of unsymmetrical squaraine cyanine dyes as cancer photodynamic therapy photosensitizers.

\begin{abstract}
The search to replace conventional cancer treatment therapies, such as chemotherapy, radiotherapy and surgery has led over the last ten years, to a substantial effort in the development of several classes of photodynamic therapy photosensitizers with desired photophysicochemical and photobiological properties. Herein we report the synthesis of 6-iodoquinoline- and benzothiazole-based unsymmetrical squaraine cyanine dyes functionalized with amine groups located in the four-membered central ring. Their photodegradation and singlet oxygen production ability, as well as their in vitro photocytotoxicity against Caco-2 and HepG2 cell lines using a $630.8 \pm 0.8 \mathrm{~nm}$ centered light-emitting diode system, were also investigated. All photosensitizer candidates displayed strong absorption within the tissue transparency spectral region $(650-850 \mathrm{~nm})$. The synthesized dyes were found to have moderate light stability. The potential of these compounds is evidenced by their cytotoxic activity against both tumor cell lines, highlighting the zwitterionic unsubstituted dye, which showed more intense photodynamic activity. Although the singlet oxygen quantum yields of these iodinated derivatives are considered low, it could be concluded that their introduction into the quinoline heterocycle was highly advantageous as it played a role in increasing selective cytotoxicity in the presence of light. Thus, the novel synthesized dyes present photophysicochemical and in vitro photobiological properties that make them excellent photosensitizer candidates for photodynamic therapy.
\end{abstract}

Keywords: unsymmetrical squaraine cyanine dyes; singlet oxygen quantum yield; photodegradation; photobiological effects; photodynamic therapy 


\section{Introduction}

Since squaric acid (3,4-dihydroxy-1,2-dioxocyclobut-3-ene) was first reported in 1959 by Cohen et al. [1], and later by other studies, as a rigid structure [2] with high chemical reactivity [3], its condensation with electron-rich precursors has been extensively studied [4-6] aiming to find products with potential applicability in several technological and biomedical areas [7-9]. Among the squaric acid derivatives, it is essential to emphasize the squaraine cyanine dyes, a core of functional dyes, first reported by Treibs and Jacob [10], known for its good photochemical stability, conductivity, sharp and intense Vis/NIR absorption and high absorption coefficients $[8,11,12]$. These photochemical and photophysical properties encourage the study of the suitability of these core of dyes to their application as photoconductive and nonlinear optical materials $[13,14]$, sensitizers for organic solar cells $[15,16]$, fluorescent probes for detection of functional groups [17], toxic substances [18-20] or biomolecules [21-23], and as photodynamic therapy (PDT) photosensitizers [9,24,25].

Cancer has become one of the biggest health problems and leading causes of death worldwide as a result of a combination of several factors, such as genetic predisposition, exposure to environmental contaminants and incorrect diet [26,27]. Since conventional treatments reveal multiple side effects, such as being extremely debilitating and poorly effective in treating some types of tumors [28], substantial progress is being made in the areas of oncology, cellular and molecular biology and medicinal chemistry to improve chemotherapy and other treatments applied to cancer patients [29].

PDT is a minimally invasive therapeutic strategy with reduced side effects that involve the death of target tissue cells by the combined action of adequate light, a photoactive molecule and molecular oxygen, which results in the production of reactive oxygen species (ROS) that promote cell structural and functional failure [30,31]. This therapeutic modality has progressed over the last few years [32,33], not only to study its potential use for the treatment of cancer, but also for dermatological [34] and ophthalmic conditions [35], such as psoriasis [36,37] and age-related macular degeneration [38], respectively. Although some PDT photosensitizers are already commercially available, mostly derived from porphyrins, these light-sensitive molecules have the disadvantage of being slowly eliminated from the body, causing skin photosensitivity $[8,39]$. Thus, several research studies have recently reported the discovery of new compounds, such as cyanines [40], squaraines [24], chlorins [41] or phthalocyanines [42] which, by appropriate structural modifications, can ideally override the gaps of first-generation photosensitizers [43].

In this work, we report the synthesis and characterization of iodoquinoline- and benzothiazole-based unsymmetrical squaraine cyanine dyes with $N$-hexyl chains and the evaluation of their properties such as photostability and singlet oxygen production ability. The in vitro phototherapeutic effects of these squaraine-based photosensitizers has been evaluated on human hepatocellular carcinoma (HepG2) and human colorectal adenocarcinoma (Caco-2) cell lines by analyzing the variation of cell viability after exposure to various irradiation and incubation conditions with the synthesized dyes. This study also aimed to understand the role of the introduction of iodine atom on photophysicochemical and photobiological properties, by comparing the results obtained in this study with those recently described by us [25].

\section{Materials and Methods}

\subsection{Chemistry}

All reagents and solvents were purchased from commercial suppliers and used without further purification. Dichloromethane was dried as described in the literature [44] and used freshly distilled. 3-Hexyl-2-methylbenzothiazol-3-ium iodide (2) [45], 3,4-dibutoxy-3-cyclobuten-1,2-dione (4) [46], 3-butoxy-4-[(3-hexylbenzothiazol-2(3H)-ylidene)methyl]-cyclobut-3-en-1,2-dione (5) [47], 3-[(3-hexyl-benzothiazol-2(3H)-ylidene)methyl]-4-hydroxycyclobut-3-en-1,2-dione (6) [47], 6-iodo-1-hexyl-quinaldine (8) [48] and 6-iodo-1-hexylquinaldinium iodide (9) [49] was prepared according to the corresponding literature procedures. Reactions were monitored by thin-layer chromatography (TLC) on aluminium plates with $0.25 \mathrm{~mm}$ of silica gel (TLC Silicagel $60 \mathrm{~F}_{254}$, Merck, 
Darmstadt, Germany), which were, whenever necessary, visualized by UV detection. Purification by column chromatography was carried out on silica gel 60 (70-230 mesh) using a mixture of ethyl acetate and petroleum ether (1:1) or $\mathrm{CH}_{2} \mathrm{Cl}_{2}$ as eluent. Melting points (m.p.) were recorded on a hot plate binocular microscope apparatus (URA Technic, Porto, Portugal) and are uncorrected. Infrared (IR) spectra were obtained using KBr pellets with an IRAffinity-1S FTIR spectrophotometer (Shimadzu, Duisburg, Germany) using Shimadzu LabSolutions IR software; $v_{\max }$ in $\mathrm{cm}^{-1}$. The intensity of the band was described as s (strong), $\mathrm{m}$ (medium) and $\mathrm{w}$ (weak). Vis/NIR absorption spectra were measured on a Lambda 25 instrument (Perkin Elmer, Waltham, USA) using PerkinElmer UV WinLab Data processor and Viewer software; $\lambda_{\max }$ in $\mathrm{nm}$. These spectra were obtained from acetonitrile (ACN), acetone (ACT), dichloromethane (DCM), DMEM, dimethylformamide (DMF), dimethyl sulfoxide (DMSO), 1,4-dioxane (DXN), ethanol (EtOH), methanol (MeOH) and tetrahydrofuran (THF). ${ }^{1} \mathrm{H}$ - and ${ }^{13} \mathrm{C}-\mathrm{NMR}$ spectra were recorded at $298.15 \mathrm{~K}$, unless otherwise stated, on an Avance III 400 NMR spectrometer (Bruker, Bremen, Germany) operating at $9.4 \mathrm{~T}$, observing ${ }^{1} \mathrm{H}$ at $400.13 \mathrm{MHz}$ and ${ }^{13} \mathrm{C}$ at $100.63 \mathrm{MHz}$ or on a Bruker Avance III 600 NMR spectrometer operating at $14.09 \mathrm{~T}$, observing ${ }^{1} \mathrm{H}$ at 600.13 and ${ }^{13} \mathrm{C}$ at $150.91 \mathrm{MHz}$. Solutions were prepared in $\mathrm{CDCl}_{3}$ or DMSO- $d_{6}$. Proton peak splittings are expressed as s (singlet), br s (broad singlet), d (doublet), $\mathrm{t}$ (triplet), br $\mathrm{t}$ (broad triplet), qt (quintet), br qt (broad quintet) or $\mathrm{m}$ (multiplet). The assignments of the carbons were made based on DEPT 90 and DEPT 135 spectra. The ${ }^{1} \mathrm{H}-\mathrm{NMR}$ and ${ }^{13} \mathrm{C}$-NMR spectra of all synthesized dyes are presented as supplementary material. High resolution electrospray ionization time-of-flight mass spectra (HRESI-TOFMS) were carried out on a microTOF (focus) spectrometer Bruker Daltonics (Bremen, Germany, located at University of Vigo).

2.1.1. Synthesis of 2-[(1-hexyl-6-iodoquinolin-2(1H)-ylidene)methyl]-4-[(3-hexylbenzothiazol3-ium-2-yl)methylene)- 3-oxocyclobut-1-en-1-olate (10)

A mixture of monosubstituted intermediate $6(0.80 \mathrm{~g}, 2.43 \mathrm{mmol})$ and quaternary ammonium salt $9(1.17 \mathrm{~g}, 2.43 \mathrm{mmol})$ was heated under reflux for $3 \mathrm{~h}$ in $n$-butanol/pyridine $(10 \%)(120 \mathrm{~mL})$. After cooling at r.t. $\mathrm{CH}_{2} \mathrm{Cl}_{2}$ was added, and the mixture was washed with cold water. The organic layer was dried over anhydrous $\mathrm{Na}_{2} \mathrm{SO}_{4}$ and the solvent removed under reduced pressure. The resulting solid was recrystallized from $\mathrm{Et}_{2} \mathrm{O} / \mathrm{CH}_{2} \mathrm{Cl}_{2} / \mathrm{MeOH}$. Yield: $53 \%$. Golden brown crystals. M.p. $143-144{ }^{\circ} \mathrm{C}$. Vis $\lambda_{\max }$ (DMSO): $726 \mathrm{~nm}, \log \varepsilon=5.26$. Vis $\lambda_{\max }$ (DMEM): $640 \mathrm{~nm}$. Vis $\lambda_{\max }(\mathrm{ACN}): 714 \mathrm{~nm}, \log \varepsilon=5.25$. Vis $\lambda_{\max }$ (ACT): $720 \mathrm{~nm}, \log \varepsilon=5.12$. Vis $\lambda_{\max }(\mathrm{DCM}): 723 \mathrm{~nm}, \log \varepsilon=5.16$. Vis $\lambda_{\max }$ (DMF): $725 \mathrm{~nm}$, $\log \varepsilon=5.14$. Vis $\lambda_{\max }(\mathrm{DXN}): 729 \mathrm{~nm}, \log \varepsilon=5.15$. Vis $\lambda_{\max }(\mathrm{EtOH}): 701 \mathrm{~nm}, \log \varepsilon=5.22$. Vis $\lambda_{\max }$ $(\mathrm{MeOH}): 695 \mathrm{~nm}, \log \varepsilon=4.45$. Vis $\lambda_{\max }$ (THF): $733 \mathrm{~nm}, \log \varepsilon=5.06$. IR $v_{\max }(\mathrm{KBr}): 3052,2912,2853$, 1729, 1549, 1450, 1304, 1253, 1177, 1087, $975 \mathrm{~cm}^{-1},{ }^{1} \mathrm{H}-\mathrm{NMR}\left(600 \mathrm{MHz}, \mathrm{CDCl}_{3}\right) \delta: 9.28(1 \mathrm{H}, \mathrm{d}, J=7.8 \mathrm{~Hz}$, $\operatorname{ArH}), 7.77(1 \mathrm{H}, \mathrm{s}, \operatorname{ArH}), 7.72(1 \mathrm{H}, \mathrm{d}, J=8.4 \mathrm{~Hz}, \operatorname{ArH}), 7.54(1 \mathrm{H}, \mathrm{d}, J=7.8 \mathrm{~Hz}, \operatorname{ArH}), 7.37(1 \mathrm{H}, \mathrm{t}, J=7.5 \mathrm{~Hz}$, ArH), $7.28(1 \mathrm{H}, \mathrm{br} \mathrm{s}, \mathrm{ArH}), 7.20(1 \mathrm{H}, \mathrm{t}, J=7.5 \mathrm{~Hz}, \mathrm{ArH}), 7.13(1 \mathrm{H}, \mathrm{d}, J=8.4 \mathrm{~Hz}, \mathrm{ArH}), 7.02(1 \mathrm{H}, \mathrm{d}, J=$ $9.0 \mathrm{~Hz}, \mathrm{ArH}), 5.89(1 \mathrm{H}, \mathrm{s}, \mathrm{C}=\mathrm{CH}), 5.73(1 \mathrm{H}, \mathrm{s}, \mathrm{C}=\mathrm{CH}), 4.10-4.06\left(4 \mathrm{H}, \mathrm{m}, \mathrm{NC}_{2}\left(\mathrm{CH}_{2}\right)_{4} \mathrm{CH}_{3}\right), 1.81(4 \mathrm{H}, \mathrm{qt}$, $\left.\mathrm{NCH}_{2} \mathrm{C}_{2}\left(\mathrm{CH}_{2}\right)_{3} \mathrm{CH}_{3}\right), 1.53\left(2 \mathrm{H}, \mathrm{qt}, \mathrm{N}\left(\mathrm{CH}_{2}\right)_{2} \mathrm{CH}_{2}\left(\mathrm{CH}_{2}\right)_{2} \mathrm{CH}_{3}\right), 1.45\left(2 \mathrm{H}, \mathrm{qt}, \mathrm{N}\left(\mathrm{CH}_{2}\right)_{2} \mathrm{C}_{2}\left(\mathrm{CH}_{2}\right)_{2} \mathrm{CH}_{3}\right)$, $1.42-1.32\left(8 \mathrm{H}, \mathrm{m}, \mathrm{N}\left(\mathrm{CH}_{2}\right)_{3}\left(\mathrm{C}_{2}\right)_{2} \mathrm{CH}_{3}\right), 0.94\left(3 \mathrm{H}, t, J=6.9 \mathrm{~Hz}, \mathrm{~N}\left(\mathrm{CH}_{2}\right)_{3} \underline{\mathrm{C}}_{3}\right), 0.91(3 \mathrm{H}, t, J=6.9 \mathrm{~Hz}$, $\left.\mathrm{N}\left(\mathrm{CH}_{2}\right)_{3} \mathrm{CH}_{3}\right)$ ppm; ${ }^{13} \mathrm{C}-\mathrm{NMR}\left(150.91 \mathrm{MHz}, \mathrm{CDCl}_{3}\right) \delta: 175.52,159.20,149.78,141.02,139.19(\mathrm{ArCH})$, 139.05, 136.67 (ArCH), $131.01(\mathrm{ArCH}), 128.53,127.73(\mathrm{ArCH}), 126.98,126.95(\mathrm{ArCH}), 123.83(\mathrm{ArCH})$, 122.04 (ArCH), $116.06(\mathrm{ArCH}), 111.26(\mathrm{ArCH}), 93.13(\mathrm{C}=\mathrm{CH}), 86.86,85.41(\mathrm{C}=\underline{\mathrm{CH}}), 47.98\left(\mathrm{NCH}_{2}\right), 46.17$ $\left(\mathrm{NCH}_{2}\right), 31.36\left(\mathrm{CH}_{2}\right), 27.22\left(\mathrm{CH}_{2}\right), 26.48\left(\mathrm{CH}_{2}\right), 26.40\left(\mathrm{CH}_{2}\right), 26.37\left(\mathrm{CH}_{2}\right), 22.55\left(\mathrm{CH}_{2}\right), 22.44\left(\mathrm{CH}_{2}\right)$, $13.92\left(\mathrm{CH}_{3}\right)$ ppm; HRESI-TOFMS m/z: $664.16035[\mathrm{M}]^{+}\left(\mathrm{C}_{34} \mathrm{H}_{37} \mathrm{IN}_{2} \mathrm{O}_{2} \mathrm{~S}^{+}\right.$, calc. 664.16149).

2.1.2. Synthesis of 3-hexyl-2-[(3-[(1-hexyl-6-iodoquinolin-2(1H)-ylidene)methyl]-2-methoxy-4oxocyclobut-2-en-1-ylidene)methyl]benzothiazol-3-ium trifluoromethanesulfonate (11)

To a solution of squaraine cyanine dye $10(0.800 \mathrm{~g}, 1.20 \mathrm{mmol})$ in anhydrous $\mathrm{CH}_{2} \mathrm{Cl}_{2}$, stirred under $\mathrm{N}_{2}$ atmosphere at r.t., was added an excess of $\mathrm{CF}_{3} \mathrm{SO}_{3} \mathrm{CH}_{3}(0.395 \mathrm{~mL}, 3.60 \mathrm{mmol})$. After $28 \mathrm{~h}$, the mixture was quenched with cold $5 \%$ aqueous $\mathrm{NaHCO}_{3}$. The organic layer, after separation by decantation, was dried over anhydrous $\mathrm{Na}_{2} \mathrm{SO}_{4}$ and the solvent removed under reduced pressure. 
Yield: $73 \%$. Bright green crystals. M.p. $215-218^{\circ} \mathrm{C}$. Vis $\lambda_{\max }$ (DMSO): $677 \mathrm{~nm}, \log \varepsilon=5.25$. Vis $\lambda_{\max }$ (ACN): $665 \mathrm{~nm}, \log \varepsilon=5.28$. Vis $\lambda_{\max }$ (ACT): $668 \mathrm{~nm}, \log \varepsilon=5.24$. Vis $\lambda_{\max }$ (DCM): $672 \mathrm{~nm}, \log \varepsilon=5.33$. Vis $\lambda_{\max }(\mathrm{DMF}): 675 \mathrm{~nm}, \log \varepsilon=5.23$. Vis $\lambda_{\max }(\mathrm{DXN}): 680 \mathrm{~nm}, \log \varepsilon=5.11$. Vis $\lambda_{\max }(\mathrm{EtOH}): 668 \mathrm{~nm}$, $\log \varepsilon=5.27$. Vis $\lambda_{\max }(\mathrm{MeOH}): 665 \mathrm{~nm}, \log \varepsilon=4.60$. Vis $\lambda_{\max }$ (THF): $671 \mathrm{~nm}, \log \varepsilon=5.26$. IR $v_{\max }$ (KBr): 2955, 2930, 1553, 1506, 1443, 1379, 1352, 1258, 1184, 1153, 1119, $1030 \mathrm{~cm}^{-1}$; ${ }^{1} \mathrm{H}-\mathrm{NMR}(600 \mathrm{MHz}$, $\left.\mathrm{CDCl}_{3}\right) \delta: 8.65(1 \mathrm{H}, \mathrm{br} \mathrm{s}, \mathrm{ArH}), 7.92(1 \mathrm{H}, \mathrm{s}, \mathrm{ArH}), 7.88(1 \mathrm{H}, \mathrm{d}, J=9.0 \mathrm{~Hz}, \mathrm{ArH}), 7.63(2 \mathrm{H}, \mathrm{t}, J=7.5 \mathrm{~Hz}$, $\operatorname{ArH}), 7.48(1 \mathrm{H}, \mathrm{t}, J=7.2 \mathrm{~Hz}, \operatorname{ArH}), 7.41(1 \mathrm{H}, \mathrm{d}, J=9.0 \mathrm{~Hz}, \operatorname{ArH}), 7.35-7.33(2 \mathrm{H}, \mathrm{m}, \operatorname{ArH}), 6.08(1 \mathrm{H}, \mathrm{s}$, $\mathrm{C}=\mathrm{CH}), 5.55(1 \mathrm{H}, \mathrm{s}, \mathrm{C}=\mathrm{CH}), 4.61\left(3 \mathrm{H}, \mathrm{s}, \mathrm{OCH}_{3}\right), 4.39\left(2 \mathrm{H}, \mathrm{t}, J=7.2 \mathrm{~Hz}, \mathrm{NC}_{2}\left(\mathrm{CH}_{2}\right)_{4} \mathrm{CH}_{3}\right), 4.32(2 \mathrm{H}$, br s, $\left.\mathrm{NC}_{2}\left(\mathrm{CH}_{2}\right)_{4} \mathrm{CH}_{3}\right), 1.81\left(4 \mathrm{H}, \mathrm{qt}, \mathrm{NCH}_{2} \mathrm{C}_{2}\left(\mathrm{CH}_{2}\right)_{3} \mathrm{CH}_{3}\right), 1.56\left(2 \mathrm{H}, \mathrm{qt}, \mathrm{N}\left(\mathrm{CH}_{2}\right)_{2} \mathrm{CH}_{2}\left(\mathrm{CH}_{2}\right)_{2} \mathrm{CH}_{3}\right)$, 1.46-1.36 (6H, m, N( $\left.\left.\mathrm{CH}_{2}\right)_{2}\left(\mathrm{CH}_{2}\right)_{2} \mathrm{CH}_{2} \mathrm{CH}_{3}\right), 1.31\left(4 \mathrm{H}, \mathrm{br} \mathrm{s}, \mathrm{N}\left(\mathrm{CH}_{2}\right)_{4} \mathrm{CH}_{2} \mathrm{CH}_{3}\right), 0.92(3 \mathrm{H}, \mathrm{t}, J=6.0 \mathrm{~Hz}$, $\left.\mathrm{N}\left(\mathrm{CH}_{2}\right)_{5} \mathrm{C}_{3}\right), 0.86\left(3 \mathrm{H}, \mathrm{t}, J=6.3 \mathrm{~Hz}, \mathrm{~N}\left(\mathrm{CH}_{2}\right)_{5} \mathrm{C}_{3}\right) \mathrm{ppm} ;{ }^{13} \mathrm{C}-\mathrm{NMR}\left(150.91 \mathrm{MHz}, \mathrm{CDCl}_{3}\right) \delta: 177.91$, 162.08, 158,77, 157.49, 151.28, $141.05(\mathrm{ArCH}), 140.59,138.40,137.32(\mathrm{ArCH}), 134.84(\mathrm{ArCH}), 128.13$ $(\mathrm{ArCH}), 128.00,126.81,125.54(\mathrm{ArCH}), 125.11(\mathrm{ArCH}), 122.27(\mathrm{ArCH}), 119.81,117.75(\mathrm{ArCH}), 113.27$ $(\mathrm{ArCH}), 91.83(\mathrm{C}=\underline{\mathrm{CH}}), 89.69,86.50(\mathrm{C}=\underline{\mathrm{CH}}), 61.30\left(\mathrm{OCH}_{3}\right), 48.95\left(\mathrm{NCH}_{2}\right), 47.12\left(\mathrm{NCH}_{2}\right), 31.43\left(\mathrm{CH}_{2}\right)$, $31.34\left(\mathrm{CH}_{2}\right), 27.84\left(\mathrm{CH}_{2}\right), 27.12\left(\mathrm{CH}_{2}\right), 26.30\left(\mathrm{CH}_{2}\right), 26.16\left(\mathrm{CH}_{2}\right), 22.46\left(\mathrm{CH}_{2}\right), 22.39\left(\mathrm{CH}_{2}\right), 13.94\left(\mathrm{CH}_{3}\right)$, $13.91\left(\mathrm{CH}_{3}\right)$ ppm; HRESI-TOFMS m/z: $679.18313\left[\mathrm{M}-\mathrm{CF}_{3} \mathrm{SO}_{3}\right]^{+}\left(\mathrm{C}_{35} \mathrm{H}_{40} \mathrm{IN}_{2} \mathrm{O}_{2} \mathrm{~S}^{+}\right.$, calc. 679.18497).

2.1.3. Synthesis of 2-[(2-amino-3-[(1-hexyl-6-iodoquinolin-2(1H)-ylidene)methyl]-4oxocyclobut-2-en-1-ylidene)methyl]-3-hexylbenzothiazol-3-ium trifluoromethanesulfonate (12)

To a solution of $\mathrm{O}$-methylated squaraine cyanine dye $\mathbf{1 1}(0.20 \mathrm{~g}, 0.24 \mathrm{mmol})$ in anhydrous $\mathrm{CH}_{2} \mathrm{Cl}_{2}$, under $\mathrm{N}_{2}$ atmosphere at r.t., was added an excess of $2 \mathrm{M}$ ammonia solution in $\mathrm{MeOH}(0.54 \mathrm{~mL}$, $1.08 \mathrm{mmol}$ ). The reaction mixture was stirred at r.t. for $22 \mathrm{~h}$ and then washed with cold water. The organic layer was dried over anhydrous $\mathrm{Na}_{2} \mathrm{SO}_{4}$, and the solvent was removed under reduced pressure. The product was recrystallized from $\mathrm{CH}_{2} \mathrm{Cl}_{2} / \mathrm{MeOH}$. Yield: $65 \%$. Green crystals. M.p. $282-285^{\circ} \mathrm{C}$ (dec.). Vis $\lambda_{\max }$ (DMSO): $705 \mathrm{~nm}, \log \varepsilon=5.17$. Vis $\lambda_{\max }$ (DMEM): $619 \mathrm{~nm}$. Vis $\lambda_{\max }(A C N): 686 \mathrm{~nm}$, $\log \varepsilon=5.36$. Vis $\lambda_{\max }(\mathrm{ACT}): 690 \mathrm{~nm}, \log \varepsilon=5.36$. Vis $\lambda_{\max }(\mathrm{DCM}): 694 \mathrm{~nm}, \log \varepsilon=5.38$. Vis $\lambda_{\max }$ (DMF): $700 \mathrm{~nm}, \log \varepsilon=5.31$. Vis $\lambda_{\max }(\mathrm{DXN}): 706 \mathrm{~nm}, \log \varepsilon=5.27$. Vis $\lambda_{\max }(\mathrm{EtOH}): 693 \mathrm{~nm}, \log \varepsilon$ $=5.38$. Vis $\lambda_{\max }(\mathrm{MeOH}): 687 \mathrm{~nm}, \log \varepsilon=5.36$. Vis $\lambda_{\max }$ (THF): $702 \mathrm{~nm}, \log \varepsilon=5.26$. IR $v_{\max }(\mathrm{KBr}):$ 3319, 3205, 2954, 2929, 1643, 1553, 1524, 1449, 1384, 1354, 1273, 1249, 1170, 1158, 1080, 1032, $977 \mathrm{~cm}^{-1}$; ${ }^{1} \mathrm{H}-\mathrm{NMR}(600 \mathrm{MHz}, \mathrm{DMSO}) \delta: 8.91(1 \mathrm{H}, \mathrm{d}, J=9.6 \mathrm{~Hz}, \mathrm{ArH}), 8.81\left(1 \mathrm{H}, \mathrm{br} \mathrm{s}, \mathrm{NH}\right.$, exchange with $\left.\mathrm{D}_{2} \mathrm{O}\right)$, $8.69\left(1 \mathrm{H}\right.$, br s, NH, exchange with $\left.\mathrm{D}_{2} \mathrm{O}\right), 8.16(1 \mathrm{H}, d, J=1.8 \mathrm{~Hz}, \mathrm{ArH}), 7.96-7.92(2 \mathrm{H}, \mathrm{m}, \mathrm{ArH}), 7.83(1 \mathrm{H}$, $d, J=9.6 \mathrm{~Hz}, \mathrm{ArH}), 7.65(1 \mathrm{H}, \mathrm{d}, J=8.4 \mathrm{~Hz}, \mathrm{ArH}), 7.55(1 \mathrm{H}, \mathrm{d}, J=9.6 \mathrm{~Hz}, \mathrm{ArH}), 7.52(1 \mathrm{H}, \mathrm{t}, J=7.8 \mathrm{~Hz}$, $\mathrm{ArH}), 7.35(1 \mathrm{H}, \mathrm{t}, J=7.8 \mathrm{~Hz}, \mathrm{ArH}), 6.10(1 \mathrm{H}, \mathrm{s}, \mathrm{C}=\underline{\mathrm{CH}}), 5.86(1 \mathrm{H}, \mathrm{s}, \mathrm{C}=\underline{\mathrm{CH}}), 4.23(4 \mathrm{H}, \mathrm{t}, J=7.5 \mathrm{~Hz}$, $\left.\mathrm{NC}_{2}\left(\mathrm{CH}_{2}\right)_{4} \mathrm{CH}_{3}\right), 1.76-1.67\left(4 \mathrm{H}, \mathrm{m}, \mathrm{NCH}_{2} \mathrm{CH}_{2}\left(\mathrm{CH}_{2}\right)_{3} \mathrm{CH}_{3}\right), 1.51\left(2 \mathrm{H}, \mathrm{qt}, \mathrm{N}\left(\mathrm{CH}_{2}\right)_{2} \mathrm{CH}_{2}\left(\mathrm{CH}_{2}\right)_{2} \mathrm{CH}_{3}\right)$, $1.42\left(2 \mathrm{H}, \mathrm{qt}, \mathrm{N}\left(\mathrm{CH}_{2}\right)_{2} \mathrm{CH}_{2}\left(\mathrm{CH}_{2}\right)_{2} \mathrm{CH}_{3}\right), 1.36-1.27\left(8 \mathrm{H}, \mathrm{m}, \mathrm{N}\left(\mathrm{CH}_{2}\right)_{3}\left(\mathrm{CH}_{2}\right)_{2} \mathrm{CH}_{3}\right), 0.90(3 \mathrm{H}, \mathrm{t}, J=6.9 \mathrm{~Hz}$, $\left.\mathrm{N}\left(\mathrm{CH}_{2}\right)_{5} \underline{\mathrm{C}}_{3}\right), 0.87\left(3 \mathrm{H}, \mathrm{t}, J=6.9 \mathrm{~Hz}, \mathrm{~N}\left(\mathrm{CH}_{2}\right)_{5} \mathrm{C}_{3}\right) \mathrm{ppm} ;{ }^{13} \mathrm{C}-\mathrm{NMR}(150.91 \mathrm{MHz}, \mathrm{DMSO}) \delta: 174.24$, 167.24, 160.27, 157.75, 155.79, 150.37, 140.64, 140.07 (ArCH), 138.27, 136.79 (ArCH), 133.67 (ArCH), 127.71 (ArCH), 127.46, 126.64, 125.25 (ArCH), $124.69(\mathrm{ArCH}), 122.68(\mathrm{ArCH}), 117.95(\mathrm{Ar}-\mathrm{CH}), 113.11$ $(\mathrm{ArCH}), 93.57(\mathrm{C}=\underline{\mathrm{CH}}), 89.60,86.02(\mathrm{C}=\underline{\mathrm{CH}}), 47.84\left(\mathrm{NCH}_{2}\right), 46.20\left(\mathrm{NCH}_{2}\right), 31.07\left(\mathrm{CH}_{2}\right), 30.95\left(\mathrm{CH}_{2}\right)$, $27.12\left(\mathrm{CH}_{2}\right), 26.63\left(\mathrm{CH}_{2}\right), 25.77\left(\mathrm{CH}_{2}\right), 25.61\left(\mathrm{CH}_{2}\right), 22.19\left(\mathrm{CH}_{2}\right), 22.06\left(\mathrm{CH}_{2}\right), 13.91\left(\mathrm{CH}_{3}\right), 13.85\left(\mathrm{CH}_{3}\right)$ ppm; HRESI-TOFMS m/z: 664.18409 [M-CF $\left.\mathrm{SO}_{3}\right]^{+}\left(\mathrm{C}_{34} \mathrm{H}_{39} \mathrm{IN}_{3} \mathrm{OS}^{+}\right.$, calc. 664.18530).

2.1.4. Synthesis of 3-hexyl-2-[(3-[(1-hexyl-6-iodoquinolin-2(1H)-ylidene)methyl]-2-methylamino4-oxocyclobut-2-en-1-ylidene)methyl]benzothiazol-3-ium trifluoromethanesulfonate (13)

To a solution of $\mathrm{O}$-methylated squaraine cyanine dye $\mathbf{1 1}(0.20 \mathrm{~g}, 0.24 \mathrm{mmol})$ in anhydrous $\mathrm{CH}_{2} \mathrm{Cl}_{2}$, under $\mathrm{N}_{2}$ atmosphere at r.t., was added an excess of $2 \mathrm{M}$ methylamine solution in THF $(0.54 \mathrm{~mL}$, $1.08 \mathrm{mmol}$ ). The reaction mixture was stirred at r.t. for $2 \mathrm{~h}$ and then washed with cold water. The organic layer was dried over anhydrous $\mathrm{Na}_{2} \mathrm{SO}_{4}$, and the solvent was removed under reduced pressure. The resulting solid was recrystallized from $\mathrm{CH}_{2} \mathrm{Cl}_{2} / \mathrm{MeOH}$. Yield: $50 \%$. Brown crystals. M.p. $246-247^{\circ} \mathrm{C}$. Vis $\lambda_{\max }$ (DMSO): $715 \mathrm{~nm}, \log \varepsilon=5.18$. Vis $\lambda_{\max }$ (DMEM): $637 \mathrm{~nm}$. Vis $\lambda_{\max }(\mathrm{ACN}): 699 \mathrm{~nm}, \log \varepsilon=5.25$. 
Vis $\lambda_{\max }(\mathrm{ACT}): 703 \mathrm{~nm}, \log \varepsilon=5.21$. Vis $\lambda_{\max }(\mathrm{DCM}): 707 \mathrm{~nm}, \log \varepsilon=5.30$. Vis $\lambda_{\max }$ (DMF): $711 \mathrm{~nm}, \log$ $\varepsilon=5.20$. Vis $\lambda_{\max }(\mathrm{DXN}): 716 \mathrm{~nm}, \log \varepsilon=5.15$. Vis $\lambda_{\max }(\mathrm{EtOH}): 702 \mathrm{~nm}, \log \varepsilon=5.28$. Vis $\lambda_{\max }(\mathrm{MeOH}):$ $698 \mathrm{~nm}, \log \varepsilon=5.25$. Vis $\lambda_{\max }$ (THF): $714 \mathrm{~nm}, \log \varepsilon=5.17$. IR $v_{\max }(\mathrm{KBr}): 3240,2953,2930,1623,1551$, 1445, 1380, 1347, 1286, 1242, 1180, 1157, 1112, 1078, 1029, $988 \mathrm{~cm}^{-1} ;{ }^{1} \mathrm{H}-\mathrm{NMR}$ (400 MHz, DMSO) $\delta: 9.02$ $\left(2 \mathrm{H}\right.$, br s, NH, exchange with $\left.\mathrm{D}_{2} \mathrm{O}\right), 9.00(1 \mathrm{H}, \mathrm{d}, J=9.6 \mathrm{~Hz}, \mathrm{ArH}), 8.88(1 \mathrm{H}, \mathrm{d}, J=9.6 \mathrm{~Hz}, \mathrm{ArH}), 8.21$ $(1 \mathrm{H}, \mathrm{s}, \mathrm{ArH}), 8.13(1 \mathrm{H}, \mathrm{s}, \mathrm{ArH}), 8.00-7.96(2 \mathrm{H}, \mathrm{m}, \operatorname{ArH}), 7.93-7.90(3 \mathrm{H}, \mathrm{m}, \mathrm{ArH}), 7.78(1 \mathrm{H}, \mathrm{d}, J=9.6 \mathrm{~Hz}$, $\operatorname{ArH}), 7.71(1 \mathrm{H}, \mathrm{d}, J=8.8 \mathrm{~Hz}, \mathrm{ArH}), 7.64(2 \mathrm{H}, \mathrm{t}, J=8.4 \mathrm{~Hz}, \mathrm{ArH}), 7.59(1 \mathrm{H}, \mathrm{d}, J=6.0 \mathrm{~Hz}, \mathrm{ArH}), 7.55(1 \mathrm{H}$, $\mathrm{d}, J=7.2 \mathrm{~Hz}, \mathrm{ArH}), 7.52-7.48(2 \mathrm{H}, \mathrm{m}, \mathrm{ArH}), 7.38(1 \mathrm{H}, \mathrm{t}, J=8.8 \mathrm{~Hz}, \mathrm{ArH}), 6.19(1 \mathrm{H}, \mathrm{s}, \mathrm{C}=\mathrm{CH}), 6.04(1 \mathrm{H}$, $\mathrm{s}, \mathrm{C}=\mathrm{CH}), 5.92(1 \mathrm{H}, \mathrm{s}, \mathrm{C}=\mathrm{CH}), 5.82(1 \mathrm{H}, \mathrm{s}, \mathrm{C}=\mathrm{CH}), 4.35\left(4 \mathrm{H}, \mathrm{br} \mathrm{t}, J=7.0 \mathrm{~Hz}, \mathrm{NC}_{2}\left(\mathrm{CH}_{2}\right)_{4} \mathrm{CH}_{3}\right), 4.26$ $\left(4 \mathrm{H}, \mathrm{brt}, J=7.0 \mathrm{~Hz}, \mathrm{NCH}_{2}\left(\mathrm{CH}_{2}\right)_{4} \mathrm{CH}_{3}\right), 3.35\left(3 \mathrm{H}, \mathrm{s}, \mathrm{NCH}_{3}\right.$, only appears in DMSO $+\mathrm{D}_{2} \mathrm{O}$ spectrum), $3.32\left(3 \mathrm{H}, \mathrm{s}, \mathrm{NCH}_{3}\right.$, only appears in DMSO $+\mathrm{D}_{2} \mathrm{O}$ spectrum), $1.72\left(8 \mathrm{H}\right.$, br qt, $\left.\mathrm{NCH}_{2} \mathrm{CH}_{2}\left(\mathrm{CH}_{2}\right)_{3} \mathrm{CH}_{3}\right)$, $1.49\left(4 \mathrm{H}\right.$, br qt, $\left.\mathrm{N}\left(\mathrm{CH}_{2}\right)_{2} \mathrm{CH}_{2}\left(\mathrm{CH}_{2}\right)_{2} \mathrm{CH}_{3}\right), 1.40\left(4 \mathrm{H}\right.$, br qt, N$\left.\left(\mathrm{CH}_{2}\right)_{2} \mathrm{CH}_{2}\left(\mathrm{CH}_{2}\right)_{2} \mathrm{CH}_{3}\right), 1.36-1.27(16 \mathrm{H}$, $\left.\mathrm{m}, \mathrm{N}\left(\mathrm{CH}_{2}\right)_{3}\left(\mathrm{CH}_{2}\right)_{2} \mathrm{CH}_{3}\right), 0.90-0.84\left(12 \mathrm{H}, \mathrm{m}, \mathrm{N}\left(\mathrm{CH}_{2}\right)_{5} \mathrm{CH}_{3}\right) \mathrm{ppm} ;{ }^{13} \mathrm{C}-\mathrm{NMR}(100.63 \mathrm{MHz}, \mathrm{DMSO}) \delta$ : 173.62, 173.54,165.36, 165.30, 160.88, 159.21, 157.22, 156.59, 155.70, 154.51, 150.55, 149.52, 140.59, 140.47, $140.21(\mathrm{ArCH}), 139.87(\mathrm{ArCH}), 138.46,138.13,136.88(\mathrm{ArCH}), 136.56(\mathrm{ArCH}), 134.16(\mathrm{ArCH}), 132.83$ $(\mathrm{ArCH}), 127.84(\mathrm{ArCH}), 127.62(\mathrm{ArCH}), 126.78,126.35,125.25(\mathrm{ArCH}), 125.10(\mathrm{ArCH}), 124.99(\mathrm{ArCH})$, $124.48(\mathrm{ArCH}), 122.76(\mathrm{ArCH}), 122.47(\mathrm{ArCH}), 121.74,119.60,118.09(\mathrm{ArCH}), 117.77(\mathrm{ArCH}), 113.35$ $(\mathrm{ArCH}), 112.94(\mathrm{ArCH}), 94.03(\mathrm{C}=\mathrm{CH}), 93.65(\mathrm{C}=\mathrm{CH}), 90.11,89.25,86.61(\mathrm{C}=\mathrm{CH}), 86.33(\mathrm{C}=\mathrm{CH}), 48.18$ $\left(\mathrm{NCH}_{2}\right), 48.00\left(\mathrm{NCH}_{2}\right), 46.41\left(\mathrm{NCH}_{2}\right), 45.70\left(\mathrm{NCH}_{2}\right), 31.10\left(\mathrm{CH}_{2}\right), 30.98\left(\mathrm{CH}_{2}\right), 30.93\left(\mathrm{CH}_{2}\right), 30.81\left(\mathrm{CH}_{2}\right)$, $30.30\left(\mathrm{NHCH}_{3}\right), 30.06\left(\mathrm{NHCH}_{3}\right), 27.24\left(\mathrm{CH}_{2}\right), 26.87\left(\mathrm{CH}_{2}\right), 26.79\left(\mathrm{CH}_{2}\right), 26.30\left(\mathrm{CH}_{2}\right), 25.76\left(\mathrm{CH}_{2}\right), 25.69$ $\left(\mathrm{CH}_{2}\right), 25.63\left(\mathrm{CH}_{2}\right), 22.23\left(\mathrm{CH}_{2}\right), 22.17\left(\mathrm{CH}_{2}\right), 22.11\left(\mathrm{CH}_{2}\right), 22.04\left(\mathrm{CH}_{2}\right), 13.93\left(\mathrm{CH}_{3}\right), 13.88\left(\mathrm{CH}_{3}\right), 13.85$

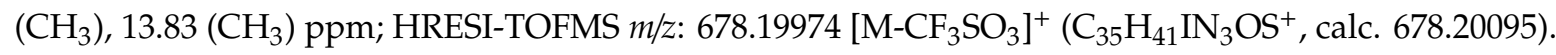

\subsection{Singlet Oxygen Formation Quantum Yields Measurement}

Singlet oxygen formation quantum yields were determined using a nitrogen laser (OBB OL-401 from Horiba) exciting at $337.1 \mathrm{~nm}$ with $0.60 \mathrm{~ns}$ pulses and $1.1 \mathrm{~mJ} /$ pulse), in air equilibrated samples. The detector was an indium gallium arsenide CCD (model i-Dus from Andor Technology Limited, Belfast, UK) working at $-60{ }^{\circ} \mathrm{C}$ coupled to a fixed spectrograph, model Shamrock 163i, also from Andor [50]. Phenazine was used as a standard at O.D. $=0.6$ in chloroform. The quantum yield values were obtained by a simple comparison of the total areas of the emission spectra determined for the standard and samples, using the same O.D. at the excitation wavelength. For each determination, an average of 100 phosphorescence spectra were used.

\subsection{Photostability Monitoring}

Working solutions of each squaraine dye at a concentration of $20 \mu \mathrm{M}$ were prepared by diluting dyes' stock solutions in DMSO at $1 \mathrm{mM}$. To each well of a 96-well plate was added in quadruplicate $100 \mu \mathrm{L}$ of each working solution. Squaraines were repetitively irradiated with suitable LED system equipment, which characterization is presented in the next section. Dyes absorbance was measured at the maximum absorption wavelength of each dye in DMSO for 60 min using Multiscan Go spectrophotometer microplate reader (Thermo Fisher Scientific, Vantaa, Finland).

\subsection{In Vitro Photobiological Evaluation}

The human colon adenocarcinoma and hepatocellular carcinoma cell lines, Caco-2 (Cell Lines Service, Eppelheim, Germany) and HepG2 (American Type Culture Collection, Rockville, USA) respectively, were grown as a monolayer culture in Dulbecco's Modified Eagle Medium (DMEM) supplemented with $10 \%(v / v)$ heat-inactivated fetal bovine serum (FBS), $1 \mathrm{mM}$ L-glutamine, $100 \mathrm{U} / \mathrm{mL}$ penicillin and $100 \mu \mathrm{g} / \mathrm{mL}$ streptomycin, at $37^{\circ} \mathrm{C}$ in a humidified atmosphere of $5 \% \mathrm{CO}_{2}$. The medium of these two cell lines was changed every two days, and cells were replated before reaching confluence. All reagents and consumables for cell culture were obtained from Gibco (Alfagene, Lisbon, Portugal). The general methods applied for handling these cell lines are already described in the literature $[51,52]$. 
At confluence, cells were trypsinized, counted, and resuspended in culture media at a density of 5 $\times 10^{4}$ cells $/ \mathrm{mL}$, and then $100 \mu \mathrm{L} /$ well of cell suspension was added to a 96-well culture plate for seeding and incubated at $37^{\circ} \mathrm{C}$ under $5 \% \mathrm{CO}_{2}$. After $24 \mathrm{~h}$ of cell growth, the medium was removed, and the cells incubated with serum-free culture medium solution of differing squaraine dyes' concentrations $(0.1,1,1.5$ and $5 \mu \mathrm{M})$. The maximum DMSO concentration used in cell viability assays did not produce significant effects on cell proliferation (data not shown). A negative control was performed exposing the cells only to the cell culture medium.

After $24 \mathrm{~h}$ of squaraine dyes incubation, cells were exposed to three different irradiation conditions: (i) 0 min of irradiation (without irradiation; cells were protected from ambient light), (ii) $7 \mathrm{~min}$ of irradiation and (iii) $14 \mathrm{~min}$ of irradiation. The irradiation was performed with a self-designed and constructed apparatus consisting of an arrangement of LEDs of required wavelength. The device was built using aluminum gallium indium phosphide LEDs (B5B-445-TL, Roithner, Vienna, Austria) with a spectral emission peak at $\lambda=630.8 \pm 0.8 \mathrm{~nm}$ with $P=4.3 \pm 0.5 \mathrm{~mW}$, operating at $20 \mathrm{~mA}$. The apparatus was placed over the 96-well plates, with the LEDs fronting the cells, and each LED irradiated a single well at approximately $1.5 \mathrm{~cm}$ away from the wellbore, as previously described [25]. After light-treatment, cells were incubated for $1 \mathrm{~h}$ or $24 \mathrm{~h}$ with irradiated dyes. Later the media containing the dye solutions was removed, and the cells were washed with phosphate-buffered saline solution (PBS; $137.0 \mathrm{mM} \mathrm{NaCl}, 2.7 \mathrm{mM} \mathrm{KCl}, 1.75 \mathrm{mM} \mathrm{KH}_{2} \mathrm{PO}_{4}, 10.0 \mathrm{mM} \mathrm{Na}_{2} \mathrm{HPO}_{4}, \mathrm{pH} 7.4$ ).

Finally, in order to assess the photodynamic effects of squaraine dyes 10, 12 and $\mathbf{1 3}$, the culture medium containing the irradiated dyes was replaced by a $10 \%(v / v)$ Alamar Blue solution diluted in a serum-free culture medium. After about 4 to $5 \mathrm{~h}$ of Alamar Blue incubation, absorbance at 570 (reduced form) and $620 \mathrm{~nm}$ (oxidized form) was read in a Multiskan EX microplate reader (MTX Labsystems, Vantaa, Finland). The data were analyzed by calculating the percentage of Alamar Blue reduction and expressed as a percentage of control (untreated cells), as previously described [51].

\section{Data Statistical Analysis}

The photobiological assays were performed in quadruplicate, and its data are expressed as mean value \pm standard deviation (mean \pm SD). Statistical significance was determined using a Student's $t$-test of the data of dye treatments and control, and differences were considered statistically significant for a $p$-value lower than 0.05 . The $\mathrm{IC}_{50}$ values determination was done from the concentration-response curves by sigmoidal fitting analysis considering a $95 \%$ confidence interval and with the bottom of the curves constrained to greater than $0 \%$ of relative cell proliferation. All data shown are representative of at least three independent experiments.

\section{Results and Discussion}

\subsection{Synthesis and Characterization}

The initial goal of this work was the synthesis of novel unsymmetrical squaraine cyanine dyes that exhibit properties inherent to those of an ideal photosensitizer molecule, aiming at the discovery of new photosensitizing potential molecules to be applied in cancer PDT.

The design of the molecules intended to be synthesized was based on the photophysical and photochemical studies already described in the literature, which reported that quinoline-based squaraines displayed higher wavelength absorption capacity than their benzothiazole- and benzoselenazole-based analogs, a photophysical property considered advantageous since, it allows greater therapeutic efficacy, as these molecules may be distributed to deeper tissue zones as they will be able to absorb and be stimulated by radiation of higher wavelength $[5,53]$. On the other hand, the introduction of heavy atoms into the dye structure, such as iodine, chlorine, or bromine, is widely described to improve its performance relative to its singlet oxygen production ability $[54,55]$. The choice of these unsymmetrical dyes also being derived from benzothiazole was due to the fact that this heterocycle correlates with notable phototherapeutic activity [56,57]. Given that increasing length 
of the pendant $N$-alkyl chains positively influences photophysical properties such as singlet oxygen production ability and maximum absorption wavelength, $N$-hexyl chains have been introduced in both heterocyclic dye moieties $[8,58]$.

Thus, unsymmetrical squaraine cyanine dyes 10-13 bearing 6-iodoquinoline and benzothiazole moieties were successfully prepared by a multistep procedure, as illustrated in Scheme 1 . The dyes preparation was initiated by the quaternization of the commercially 2-methylbenzothiazole $\mathbf{1}$, through the alkylation of the nitrogen atom with iodohexane, resulting in the synthesis of the quaternary ammonium salt 2 [45]. Then, dibutyl squarate (4), obtained by the reaction between squaric acid (3) and $n$-butanol, reacted with the benzothiazole-based quaternary ammonium salt 2 to afford the monosubstituted intermediate $5[46,47]$. This latter intermediate was posteriorly hydrolyzed using a $40 \%$ sodium hydroxide aqueous solution, and the resulting sodium salt was protonated with a $2 \mathrm{M}$ hydrochloric acid solution, yielding the key monosubstituted intermediate 6 [47].

The zwitterionic unsymmetrical squaraine dye $\mathbf{1 0}$ was prepared by a base-catalyzed condensation of intermediate $\mathbf{6}$ with the iodoquinoline-based quaternary ammonium salt $\mathbf{9}$, in a n-butanol/pyridine refluxing mixture. Ammonium salt 9 was prepared by the alkylation of 6-iodo-1-hexylquinaldine (8) with iodohexane [49], obtained by the described Doebner-Miller reaction between 4-iodoaniline (7) and crotonaldehyde in hydrochloric acid [48,59]. Methylation of the unsubstituted squaraine dye $\mathbf{1 0}$ with methyl trifluoromethanesulfonate produced the $O$-methyl ether intermediate 11 [4]. Finally, the aminosquaraine cyanine dyes $\mathbf{1 2}$ and $\mathbf{1 3}$ were obtained by nucleophilic substitution of the methoxy group of the $O$-methyl derivative $\mathbf{1 1}$ by ammonia and methylamine solutions, respectively [4,25]. As far as we know, all the synthesized squaraine cyanine dyes are not described in the literature, and their synthesis and spectroscopic characterization are herein presented for the first time.

The main features in the ${ }^{1} \mathrm{H}-\mathrm{NMR}$ spectra of dyes 10-13 (Figures S1, S3 and S5) are the signals corresponding to the methine-protons. For 10, 11 and 12, the protons above referred appear at $\delta 5.89$ and 5.73, 6.08 and 5.55, 6.10 and $5.86 \mathrm{ppm}$, respectively, as two singlets since these dyes have two different heterocycle rings. In the case of dye 13 (Figure 88 ), two additional singlets were observed in that region of the spectrum $(6.19,6.04,5.92$ and $5.82 \mathrm{ppm})$ as result of the hindrance of free rotation of the $N$-methylamine group, due to the partial character of the double bond between the nitrogen atom and the carbon atom of the four-membered ring, that should promote the non-equivalence of chemical environments. This phenomenon was previously observed in the NMR spectra of several symmetrical aminosquaraine cyanine dyes [24,60] and unsymmetrical aminosquaraine cyanine dyes [25]. It is also noted that in the spectrum of $\mathbf{1 3}$ the peaks of the $\mathrm{NCH}_{3}$ groups are under the water peak of the solvent but appear in the spectrum with $\mathrm{D}_{2} \mathrm{O}$, at the chemical shifts of 3.35 and $3.32 \mathrm{ppm}$ as two singlets of three protons each. Another important feature was observed in the ${ }^{13} \mathrm{C}-\mathrm{NMR}$ spectra of dye $\mathbf{1 3}$ (Figure S10) where the four signals that appeared at $\delta 94.03,93.65,86.61$ and $86.33 \mathrm{ppm}$ were assigned to the methine-carbons. In the spectra of the another dyes 10-12, as expected, only two signals appear for each of the methine-carbons (Figures S2, S4 and S7). 


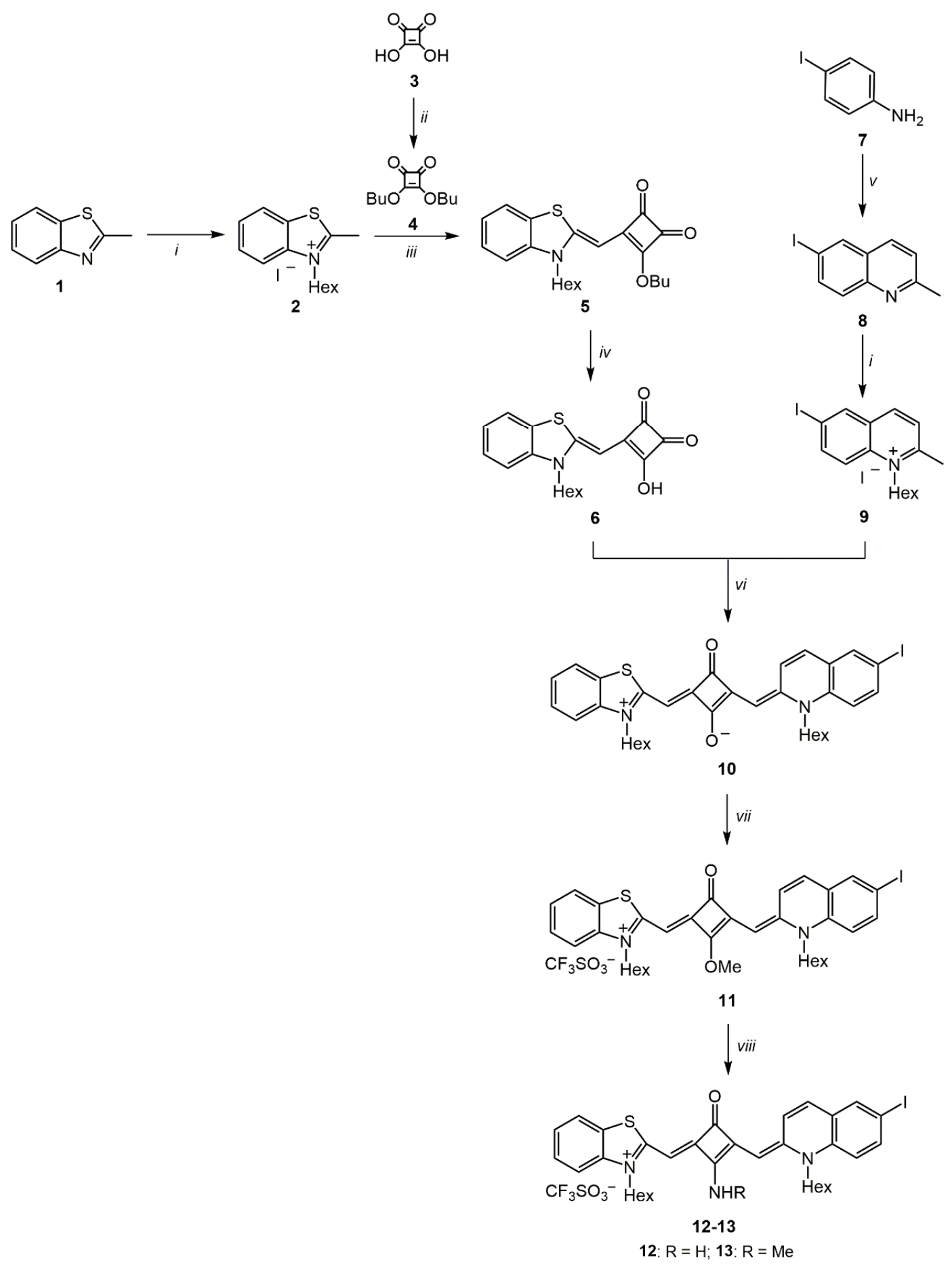

Scheme 1. Synthesis of iodoquinoline- and benzothiazole-derived squaraine cyanine dyes. Experimental conditions: (i) iodohexane, acetonitrile, reflux; (ii) n-butanol, reflux; (iii) triethylamine, ethanol, reflux; (iv) 1: sodium hydroxide aqueous solution $(40 \%), 90{ }^{\circ} \mathrm{C} ; 2$ : hydrochloric acid aqueous solution (2M); (v) 1: crotonaldehyde, hydrochloric acid (6M), toluene, reflux; 2 : sodium hydroxide aqueous solution (6M); vi) n-butanol/pyridine (10\%), reflux; (vii) methyl trifluoromethanesulfonate, dry dichloromethane, nitrogen atmosphere, room temperature (r.t.); (viii) ammonia or methylamine solution (2M), dry dichloromethane, nitrogen atmosphere, r.t.

\subsection{Photophysical Properties}

One of the most significant advances to be improved in PDT is the progression to the treatment of pathologies originating from deeper tissues, which can barely be treated with current porphyrin-based 
photosensitizers [61]. Thus, these light-sensitive compounds should possess photophysical properties such as high absorption capacity within the so-called "phototherapeutic window" (650-850 nm) and great singlet oxygen quantum yield. The photosensitizers that absorb in this electromagnetic spectrum region are the ones that can be the most easily excited in deeper tissues, since our body's constituents, such as proteins and other biomolecules, do not absorb radiation at this spectral range [62,63]. Once the photodynamic activity of a photosensitizer may be due to two reaction types, type I or type II reactions [64], the singlet oxygen quantum yield measurement is relevant for this study since this value reflects the ability of new photosensitizing molecules to produce this highly cytotoxic ROS [55] and allows us to infer about the nature of the main reaction type to be produced in biological media [8].

All the prepared dyes exhibited sharp and intense absorption in the Vis/NIR region, matching the tissue transparency spectral region (Figure 1; Table 1). In DMSO, the four-membered central ring unsubstituted squaraine dye $\mathbf{1 0}$ displayed absorption at longer wavelengths than the aminosquaraine ones (12 and 13), in which the insertion of amine groups was found to produce a slight hypsochromic effect [4] (Figure 1. Compared to the non-iodinated analog dyes reported in our previous study [25], there is a bathochromic shift of at least $10 \mathrm{~nm}$, so the introduction of this heavy atom influenced this photophysical property. When dissolved in Dulbecco's Modified Eagle Medium (DMEM), the dyes exhibited broader absorption bands, behavior possibly explained by the formation of aggregates in this aqueous medium [65] (Figure 1). The acquisition of these spectra in this culture medium is due to the need to construct a light source that emits radiation close to the maximum absorption wavelength of the dyes in the solvent where cytotoxicity assays were carried out so that the squaraines perform the maximum activity. O-methyl ether dye $\mathbf{1 1}$ was not entered in this photodynamic study, and it was not shown the cell culture media spectra since it easily hydrolyzes in aqueous medium yielding its unsubstituted precursor 10.
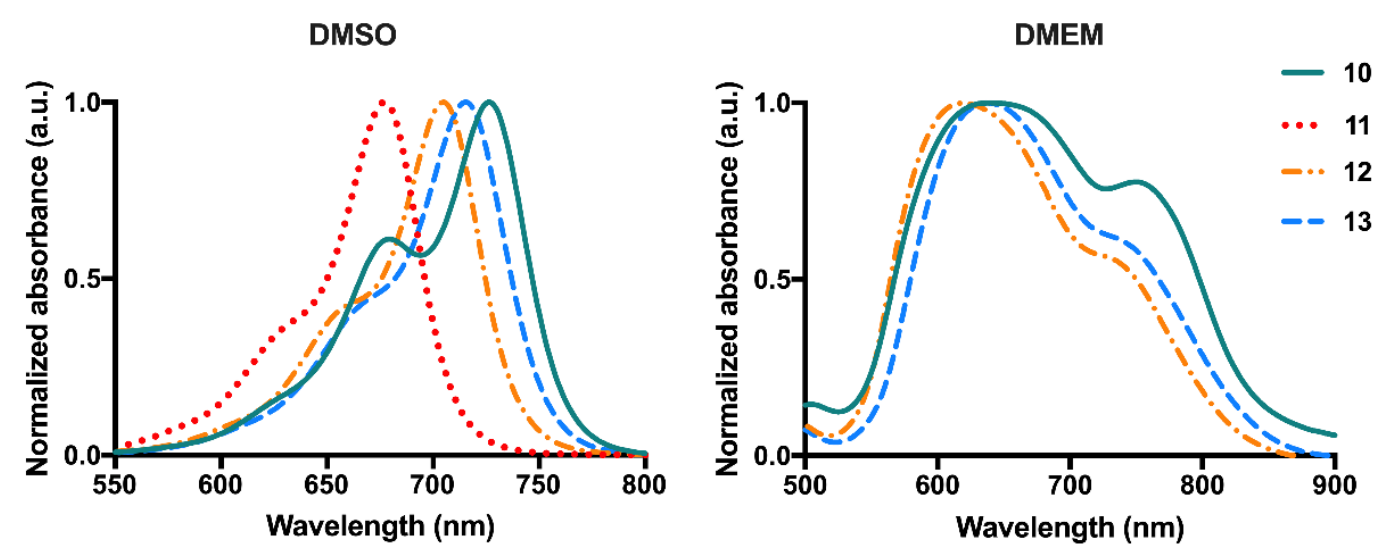

Figure 1. Vis/NIR absorption spectra obtained in dimethyl sulfoxide (DMSO) and in Dulbecco's Modified Eagle Medium (DMEM) dye solutions. Absorbance was normalized and is presented as arbitrary units (a.u.).

Table 1. Relevant Vis/NIR spectral data and singlet oxygen quantum yields $\left(\Phi_{\Delta}\right)$ of squaraine cyanine dyes 10-13.

\begin{tabular}{ccccc}
\hline \multirow{2}{*}{ Dye } & \multicolumn{2}{c}{ DMSO } & DMEM & \multirow{2}{*}{$\boldsymbol{\Phi}_{\boldsymbol{\Delta}}$} \\
\cline { 2 - 4 } & $\boldsymbol{\lambda}_{\max }(\mathbf{n m})$ & $\log \varepsilon \mathbf{( M}^{\left.-\mathbf{1} \cdot \mathbf{c m}^{-\mathbf{1}}\right)}$ & $\lambda_{\max }(\mathbf{n m})$ & \\
\hline $\mathbf{1 0}$ & 726 & 5.26 & 640 & 0.03 \\
$\mathbf{1 1}$ & 677 & 5.25 & - & - \\
$\mathbf{1 2}$ & 705 & 5.17 & 619 & 0.03 \\
$\mathbf{1 3}$ & 715 & 5.18 & 637 & 0.05 \\
\hline
\end{tabular}

To evaluate the photosensitizing ability of the synthesized dyes, the singlet oxygen formation quantum yields were measured in chloroform, and phenazine was used as a standard for its 
determination, as already described [55] (Table 1). In general, all iodinated dyes displayed quantum yields of less than 0.1 , which is considered very low. Thus, compared to the non-iodinated dyes that we reported [25] and contrary to what is described in the literature [9], the heavy atom introduction into the heterocyclic quinoline moiety does not produced an increase in the singlet oxygen production ability of these dyes. Although reported as a crucial property in the phototherapeutic activity of a photosensitizer, as this ROS is highly relevant in biological systems [66], photosensitizing compounds with low singlet oxygen generation ability may exhibit consistent photodynamic effects resulting from the marked production of type I reactions $[25,67]$.

In Figure 2, the normalized Vis/NIR absorption spectra of the squaraine dyes 10-13 in acetonitrile, acetone, dichloromethane, dimethylformamide, dimethyl sulfoxide, 1,4-dioxane, ethanol, methanol and tetrahydrofuran are presented. The relevant spectra data are summarized in Table 2. Regardless of the solvent polarity, all compounds showed a narrow absorption band in the Vis/NIR region and high molar extinction coefficient values $\left(4.0<\log \varepsilon\left(\mathrm{M}^{-1} \cdot \mathrm{cm}^{-1}\right)<5.5\right)$ in agreement with $\pi$ - $\pi^{*}$ transitions. The introduction of the methoxy group and amines into the four-membered central ring had effects on the maximum absorption wavelength, proposing that the electronic levels involved in the $\pi-\pi^{*}$ transition have different energies. Additionally, the formation of a hypsochromic shoulder, a typical photophysical characteristic of this core of dyes, is also observable regardless of the solvent.

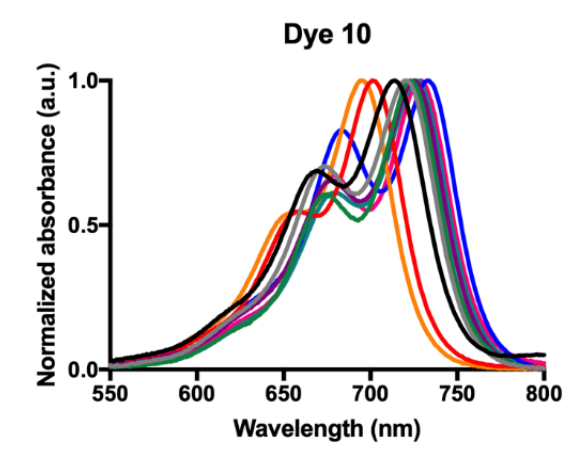

Dye 12

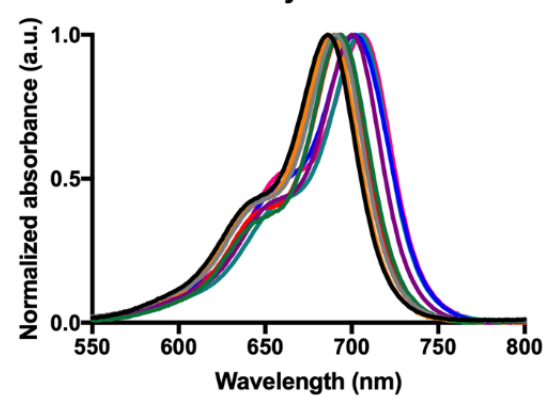

Dye 11

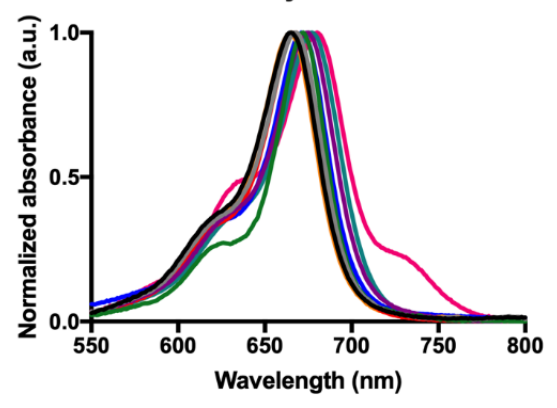

Dye 13

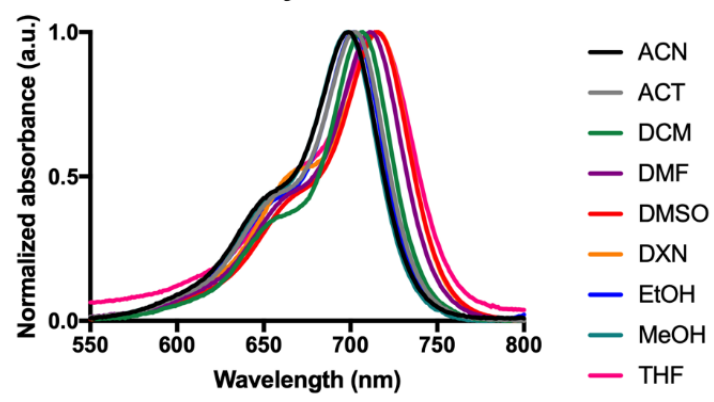

Figure 2. Vis/NIR absorption spectra of squaraine cyanine dyes $\mathbf{1 0 - 1 3}$ obtained in acetonitrile (ACN), acetone (ACT), dichloromethane (DCM), dimethylformamide (DMF), dimethyl sulfoxide (DMSO), 1,4-dioxane (DXN), ethanol (EtOH), methanol (MeOH) and tetrahydrofuran (THF). Absorbance was normalized and is presented as arbitrary units (a.u.). 
Table 2. Vis/NIR absorption data of the squaraine cyanine dyes $\mathbf{1 0 - 1 3}$ in acetonitrile (ACN), acetone (ACT), dichloromethane (DCM), dimethylformamide (DMF), 1,4-dioxane (DXN), ethanol (EtOH), methanol $(\mathrm{MeOH})$ and tetrahydrofuran $(\mathrm{THF})\left(\lambda_{\max }\right.$ in $\mathrm{nm}$ and $\log \varepsilon$ in $\mathrm{M}^{-1} \cdot \mathrm{cm}^{-1}$.

\begin{tabular}{ccccccccc}
\hline \multirow{2}{*}{ Solvent } & \multicolumn{2}{c}{ Dye 10 } & \multicolumn{2}{c}{ Dye 11 } & \multicolumn{2}{c}{ Dye 12 } & \multicolumn{2}{c}{ Dye 13 } \\
\cline { 2 - 9 } & $\lambda_{\max }$ & $\log \varepsilon$ & $\lambda_{\max }$ & $\log \varepsilon$ & $\lambda_{\max }$ & $\log \varepsilon$ & $\lambda_{\max }$ & $\log \varepsilon$ \\
\hline ACN & 714 & 5.25 & 665 & 5.28 & 686 & 5.36 & 699 & 5.25 \\
\hline ACT & 720 & 5.12 & 668 & 5.24 & 690 & 5.36 & 703 & 5.21 \\
\hline DCM & 723 & 5.16 & 672 & 5.33 & 694 & 5.38 & 707 & 5.30 \\
\hline DMF & 725 & 5.14 & 675 & 5.23 & 700 & 5.31 & 711 & 5.20 \\
\hline DXN & 729 & 5.15 & 680 & 5.11 & 706 & 5.27 & 716 & 5.15 \\
\hline EtOH & 701 & 5.22 & 668 & 5.27 & 693 & 5.38 & 702 & 5.28 \\
\hline MeOH & 695 & 4.45 & 665 & 4.60 & 687 & 5.36 & 698 & 5.25 \\
\hline THF & 733 & 5.06 & 671 & 5.26 & 702 & 5.26 & 714 & 5.17 \\
\hline
\end{tabular}

\subsection{Photodegradation Evaluation}

Since photosensitizers are ideally tools that produce ROS only in the presence of radiation, the stability evaluation of these compounds when exposed to this condition is of particular interest. Photodegradation of the potential photosensitizing candidate is considered a disadvantage since the destruction of the light-sensitive molecule in other products may complicate the interpretation of the experimental results as well as lead to decreased efficiency of ROS production $[68,69]$. Nevertheless, most commercial photosensitizing drugs used in tumor photodynamic treatment, such as porphyrins and chlorines, have poor photostability [70]. It is known that squaraine dyes are a class of compounds with fair photostability and that this photochemical property is mainly related to the nature of heterocyclic units [71].

For the photodegradation monitoring, solutions of each unsymmetrical squaraine dye in DMSO were irradiated by a light-emitting diode (LED) system centered at $630.8 \pm 0.8 \mathrm{~nm}$ for periods of $1 \mathrm{~min}$ from 0 to $20 \mathrm{~min}, 2 \mathrm{~min}$ from 20 to $40 \mathrm{~min}$ and $5 \mathrm{~min}$ from $40 \mathrm{~min}$ to $60 \mathrm{~min}$ (Figure 3). All dyes showed moderate photostability, except for the precursor $O$-methylated dye 11, which degradation over the irradiation time was more pronounced. The remaining dyes showed very similar light stability over the studied time period. Unsubstituted dye 10 and aminosquaraines $\mathbf{1 2}$ and 13, after 14 min of irradiation, longer irradiation time performed in in vitro cytotoxicity assays, showed reduced degradation. Thus, we can consider that the in vitro photodynamic effects produced up to this irradiation period are of the dye in question, without significant interference of degradative compounds.

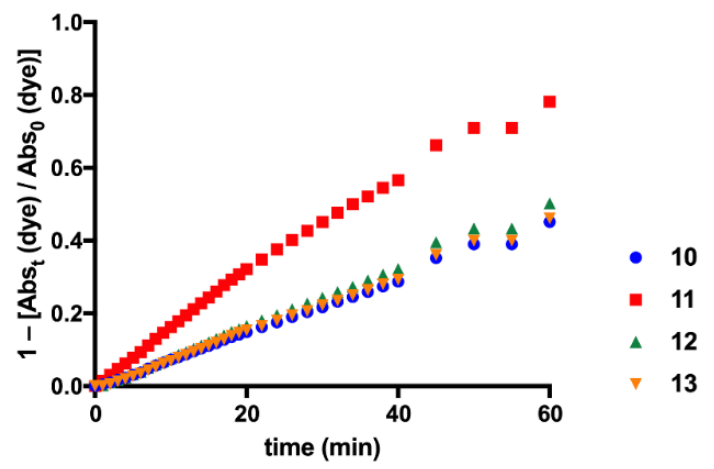

Figure 3. Photodegradation evaluated of squaraine cyanine dyes 10-13. DMSO squaraine dye solutions were irradiated with a LED system centered at $630.8 \pm 0.8 \mathrm{~nm}$ with the power of $4.3 \pm 0.5 \mathrm{~mW}$ and their absorbance read over $60 \mathrm{~min}\left(\mathrm{Abs}_{\mathrm{t}}(\mathrm{dye})\right.$ : absorbance of squaraine dye when irradiated at time $\mathrm{t} ; \mathrm{Abs}_{0}$ (dye): absorbance of squaraine dye without irradiation). 


\subsection{Photocytotoxicity Studies}

An efficient PDT photosensitizer needs to possess relevant photocytotoxicity and low dark toxicity [30]. The evaluation of the toxicity level of novel compounds using cell lines as in vitro models is recurrent, as they have prolonged life expectancy, phenotypic stability and easy handling [72]. HepG2 is a human hepatoma nontumorigenic cell line with high growth and proliferation rates that allows the hepatotoxicity and drug metabolism research [72]. The photocytotoxicity study in the human colorectal carcinoma cell line Caco-2 is of particular interest as these cells have morphological and biochemical characteristics similar to those of the intestinal epithelium, as well as being an ideal in vitro model of the third most common malignant pathology and second cancer-related cause of death $[73,74]$.

Thus, to determine the concentration range at which a in vitro phototherapeutic effect is produced, Caco-2 and HepG2 cells were exposed to increasing concentrations $(0.1,1.0,5.0$ and $10.0 \mu \mathrm{M})$ of squaraine cyanine dyes 10,12 and 13. Irradiation was executed by a self-made LED system centered at $630.8 \pm 0.8 \mathrm{~nm}$ with a power of $4.3 \pm 0.5 \mathrm{~mW}$ for periods of 7 or $14 \mathrm{~min}$, and a non-irradiated control was also performed. Cell viability was evaluated at $1 \mathrm{~h}$ or $24 \mathrm{~h}$ after irradiation by using Alamar Blue, a reliable and straightforward colorimetric method, which has several advantages compared to standard techniques such as 3-[4,5-dimethylthiazole-2-yl]-2,5-diphenyltetrazolium bromide (MTT) reduction assay, due to its high sensitivity, stability and minimal cell toxicity that allows continuous viability monitoring [75]. Dark and light cytotoxicity of culture medium containing the maximum DMSO concentration used were also assessed, and data confirmed that these did not influence the cell viability percentage (data not shown).

All the squaraine cyanine dyes induced a decrease of Caco-2 cell proliferation and dose-dependent cytotoxicity was observed. Interestingly, the unsubstituted squaraine dye $\mathbf{1 0}$ showed the most significant phototherapeutic potential in the Caco-2 cell line compared to aminosquaraine dyes, since that at 5.0 and $10.0 \mu \mathrm{M}$ the presence of radiation was necessary to reduce cell viability in more than $30 \%$ (threshold level for cytotoxicity according to the Generally Recognised As Safe (GRAS) standards [76]) (Figure 4). The exposure times of Caco-2 cells to synthesized squaraine dyes showed to have an impact on dye cytotoxicity. Proof of this is the abrupt decrease in cell viability occurred at the concentration of $1.0 \mu \mathrm{M}, 23 \mathrm{~h}$ after $1 \mathrm{~h}$ exposure reading with the irradiated dye, as well as at $10.0 \mu \mathrm{M}$ without irradiation, regardless of the dye evaluated. The substitution of hydrogen atom by the methyl group did not potentiate the photodynamic activity of dye $\mathbf{1 3}$ since both aminosquaraines (12 and 13) showed very similar cytotoxicity results for the colorectal adenocarcinoma cells. The latter produced a good phototherapeutic effect at $5.0 \mu \mathrm{M}$ when cells were exposed for $1 \mathrm{~h}$ to irradiated dye and at 1.0 and $5.0 \mu \mathrm{M}$ when cells were analysed $24 \mathrm{~h}$ after exposure. Thus, the incubation of the cells over a more extended time period made it possible to increase the cytotoxic effect of these aminosquaraine dyes produced in vitro as photodynamic effect. Note that at the $1.0 \mu \mathrm{M}$ concentration and an incubation time of $24 \mathrm{~h}$, aminosquaraines can only abruptly reduce cell viability at $14 \mathrm{~min}$ of irradiation, so that the amount of energy absorbed may be strictly linked to the photosensitizer candidates' biological action. 
$1 \mathrm{~h}$ after irradiation
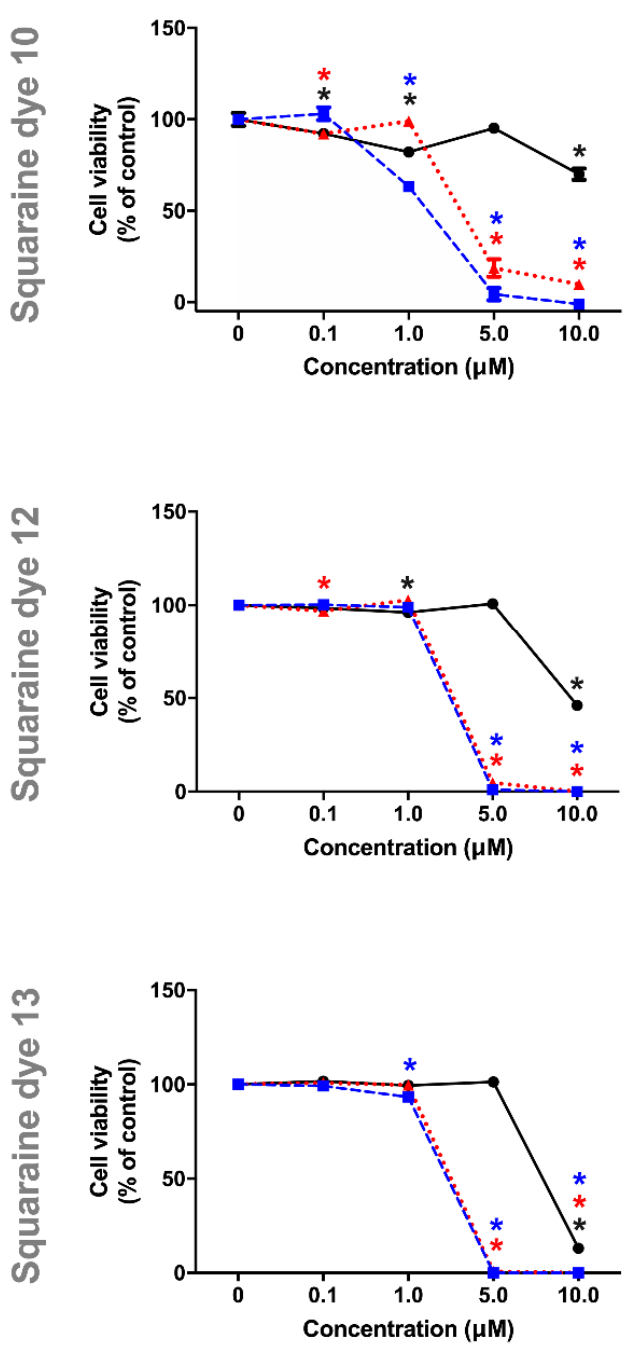

$24 \mathrm{~h}$ after irradiation
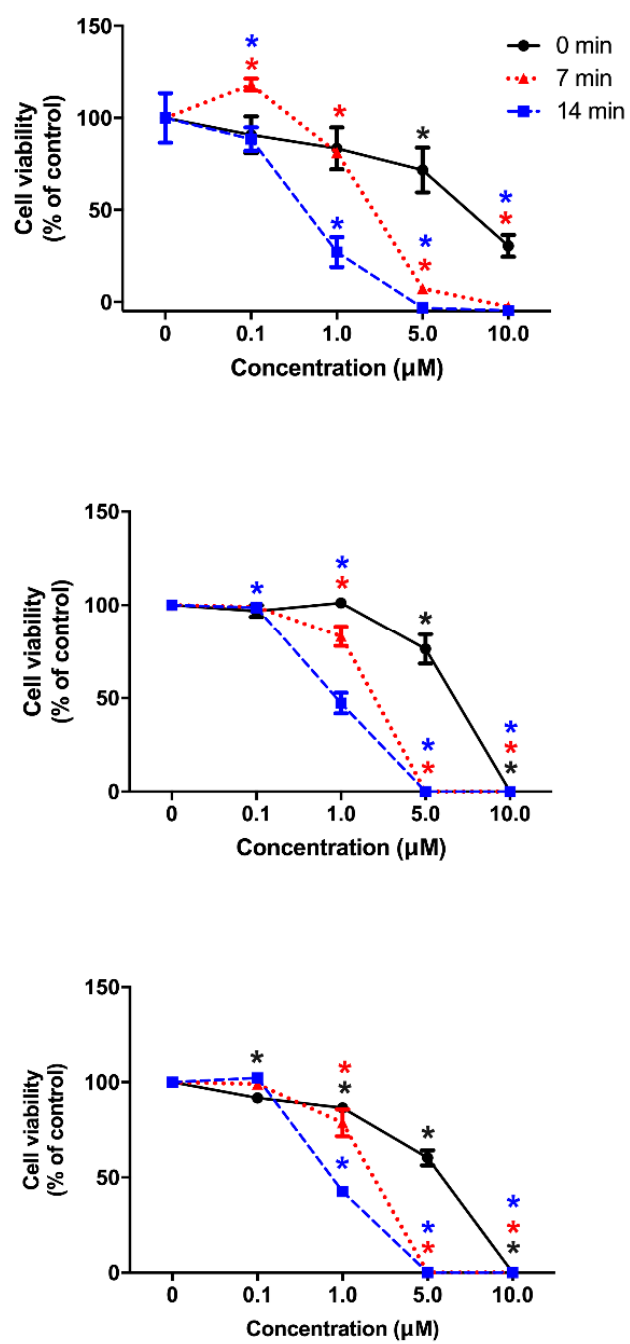

Figure 4. In vitro phototherapeutic effects of squaraine cyanine dyes 10, 12 and $\mathbf{1 3}$ on Caco-2 cells. Cells were incubated for $24 \mathrm{~h}$ with the dyes at several concentrations $(0.1,1.0,5.0$ and $10.0 \mu \mathrm{M})$ and then exposed to the radiation of a LED system centered at $630.8 \pm 0.8 \mathrm{~nm}$ and with the power of 4.3 $\pm 0.5 \mathrm{~mW}$ for 0,7 and $14 \mathrm{~min}$. Irradiated dyes were in contact with the cells for $1 \mathrm{~h}$ or for $24 \mathrm{~h}$. Data are expressed as a percentage of control (untreated cells) and presented as mean \pm standard deviation of three independent assays performed in quadruplicate. Data points without error bars showed no differences between the independent tests performed. Experiments with $t$-Student's statistical significance compared to the negative control are signed by an asterisk ${ }^{*}$ ) of the color relative to the irradiation time.

The dyes showed different degrees of cytotoxicity depending on the cell lines under study. These differences are due to the fact that each cell line is a system with its unique biological characteristics, nevertheless of whether they originate from the same tissue, species or histological tumor type, given the individual properties of the biological material from which the cell lines have been established and heterogeneity of the tumor cells [77,78]. Among the three dyes, the one that stood out most in the HepG2 cell line was the unsubstituted dye 10 (Figure 5). This dye produces, compared to the Caco-2 cell line, a more evident photodynamic effect at 5 and $10 \mu \mathrm{M}$ concentrations, $1 \mathrm{~h}$ after irradiation. This effect is explained by the total absence of hepatocytotoxicity in the absence of radiation, which despite showing less than $30 \%$ decrease in cell viability, was statistically significant at the $10 \mu \mathrm{M}$ concentration for the colorectal carcinoma cell line. 
$1 \mathrm{~h}$ after irradiation
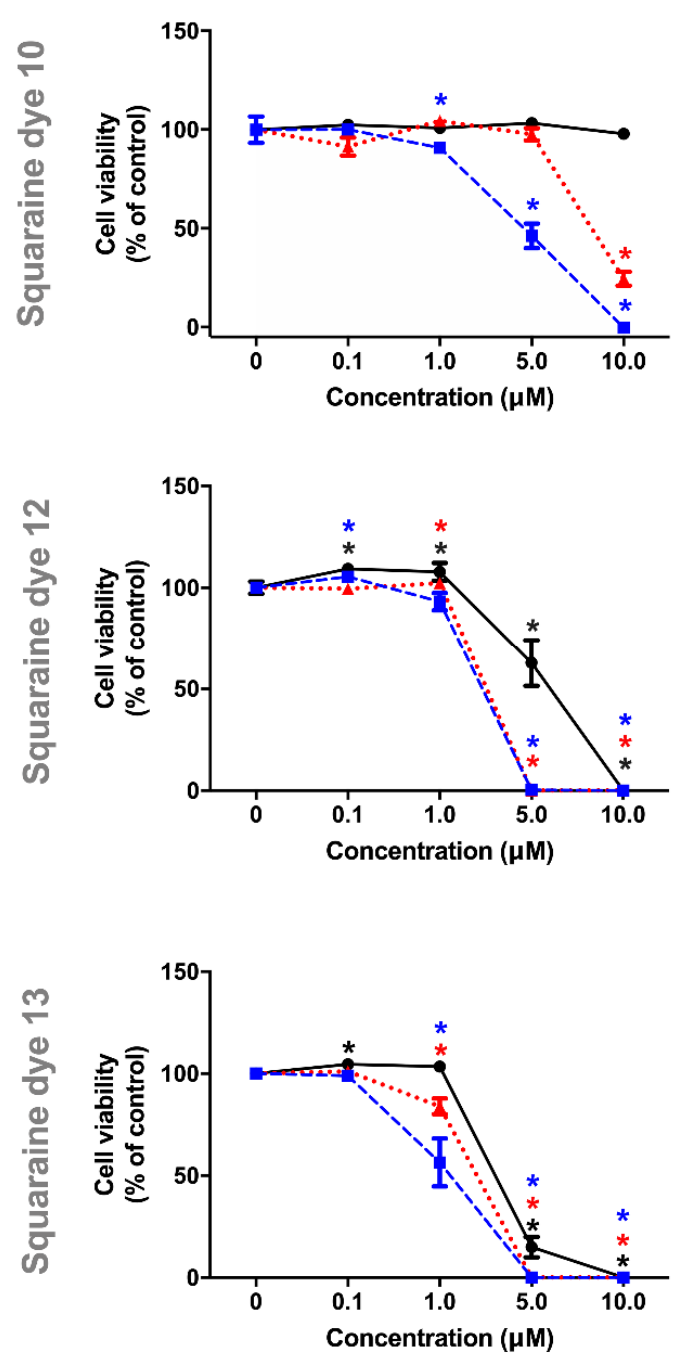

$24 \mathrm{~h}$ after irradiation
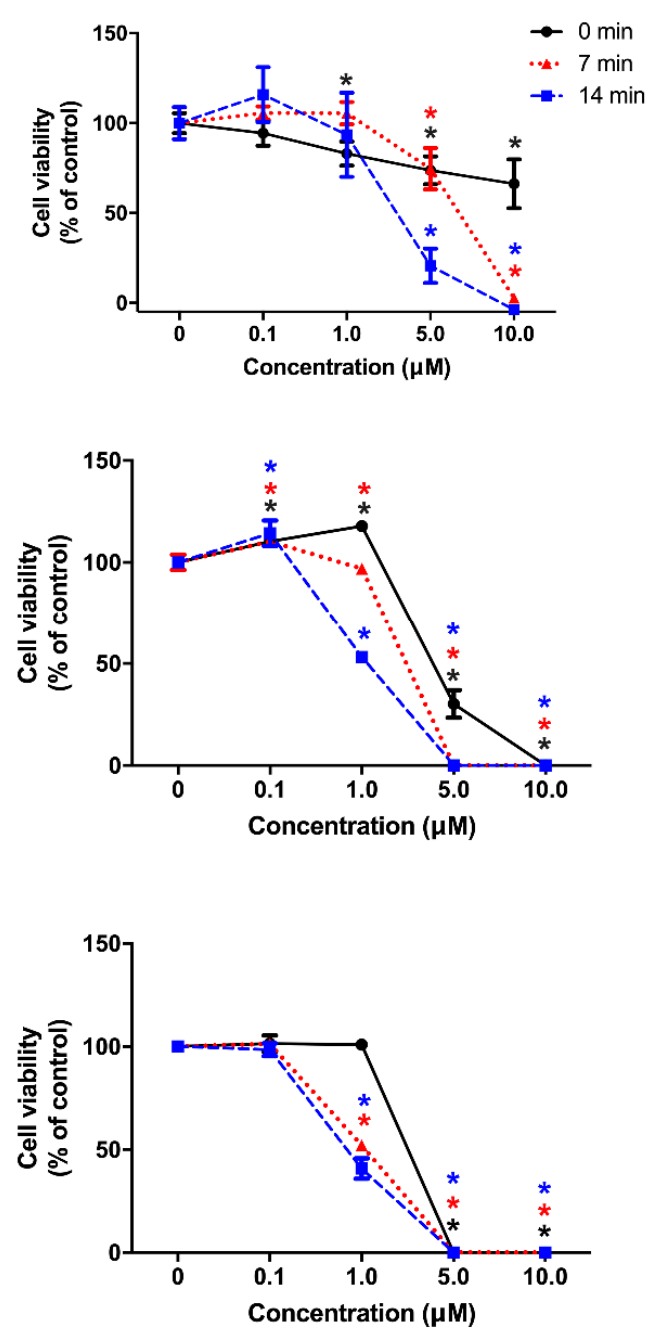

Figure 5. In vitro phototherapeutic effects of squaraine cyanine dyes 10, 12 and $\mathbf{1 3}$ on HepG2 cells. Cells were incubated for $24 \mathrm{~h}$ with the dyes at several concentrations $(0.1,1.0,5.0$ and $10.0 \mu \mathrm{M})$ and then exposed to the radiation of a LED system centered at $630.8 \pm 0.8 \mathrm{~nm}$ and with the power of 4.3 $\pm 0.5 \mathrm{~mW}$ for 0,7 and $14 \mathrm{~min}$. Irradiated dyes were in contact with the cells for $1 \mathrm{~h}$ or for $24 \mathrm{~h}$. Data are expressed as a percentage of control (untreated cells) and presented as mean \pm standard deviation of three independent assays performed in quadruplicate. Data points without error bars showed no differences between the independent tests performed. Experiments with $t$-Student's statistical significance compared to the negative control are signed by an asterisk $\left({ }^{*}\right)$ of the color relative to the irradiation time.

In contrast to the Caco-2 cell line, in which aminosquaraine 12 showed therapeutic properties, this dye evidenced weak photodynamic activity for HepG2 cells, since the conditions in which light produces reduced cell viability also decreased in the absence of irradiation. Finally, the compound bearing methylamino group 13 shows a slight photodynamic activity at a concentration of $1 \mu \mathrm{M}$ under both irradiation conditions and times after irradiation. Similar effects of these dyes were produced in Caco-2 cells, but at a concentration of $5 \mu \mathrm{M}$, so the compound showed higher potency for the hepatocyte cell line.

Furthermore, the half-inhibitory concentration $\left(\mathrm{IC}_{50}\right)$ of the evaluated squaraines was determined for each incubation and irradiation times of both studied cell lines by sigmoidal fitting analysis, and these values confirm the relevance and phototherapeutic ability of unsubstituted dye 10 (Table 3). 
Of the evaluated compounds, dye $\mathbf{1 0}$ has the highest $\mathrm{IC}_{50}$ values in the absence of light, regardless of cell line and incubation time, indicating low dark toxicity, and clearly lower $\mathrm{IC}_{50}$ values when irradiated, specifying good phototherapeutic response. The sensitivity of the hepatocyte cell line to aminosquaraine dyes $\mathbf{1 2}$ and $\mathbf{1 3}$ is evidenced by the significantly lower $\mathrm{IC}_{50}$ values under most conditions compared to the colorectal cell line (Table 3). Nevertheless, it is noteworthy that the aminosquaraine dyes produced considerably lower $\mathrm{IC}_{50}$ values when irradiated, so their in vitro photocytotoxic activity is not questioned. An inverse proportionality of photocytotoxicity to irradiation time and incubation time with irradiated dyes is also reflected in these values, since the longer the incubation and irradiation times, the lower the $\mathrm{IC}_{50}$ values.

Table 3. Calculated $\mathrm{IC}_{50}$ values $(\mu \mathrm{M})$ for squaraine cyanine dyes $\mathbf{1 0}, \mathbf{1 2}$ and $\mathbf{1 3}$ in Caco-2 and HepG2 cells (95\% confidence level) for the different irradiation treatments $(0,7$ and $14 \mathrm{~min})$ and irradiated dyes' incubation times ( 1 and $24 \mathrm{~h}$ ).

\begin{tabular}{cccccc}
\hline \multirow{2}{*}{ Dye } & \multirow{2}{*}{ Irradiation Time } & \multicolumn{2}{c}{ Caco-2 } & \multicolumn{3}{c}{ HepG2 } \\
\cline { 3 - 6 } & & $\mathbf{1 ~ h}$ & $\mathbf{2 4} \mathbf{h}$ & $\mathbf{1 ~ h}$ & $\mathbf{2 4} \mathbf{~ h}$ \\
\hline \multirow{3}{*}{$\mathbf{1 0}$} & $0^{\prime}$ & $>10$ & 8.811 & $>10$ & $>10$ \\
& $7^{\prime}$ & 2.277 & 2.320 & 9.606 & 5.068 \\
& $14^{\prime}$ & 1.655 & 0.456 & 3.291 & 2.306 \\
\hline \multirow{3}{*}{$\mathbf{1 2}$} & $0^{\prime}$ & $>10$ & 4.383 & 4.491 & 2.116 \\
& $7^{\prime}$ & 1.497 & 1.069 & 1.478 & 1.182 \\
& $14^{\prime}$ & 1.322 & 0.989 & 1.145 & 0.903 \\
\hline \multirow{2}{*}{$\mathbf{1 3}$} & $0^{\prime}$ & 9.632 & 3.411 & 2.316 & 1.645 \\
& $7^{\prime}$ & 1.973 & 1.256 & 1.414 & 0.800 \\
& $14^{\prime}$ & 1.567 & 0.751 & 1.441 & 0.732 \\
\hline
\end{tabular}

In our last study [25], we concluded that unsymmetrical benzothiazole- and quinoline-based squaraine cyanine dyes has desirable photophysical and photobiological properties for their potential application as PDT photosensitizers, however, changes in their structure would be necessary to reduce dark cytotoxicity. Considering that it is already described in the literature that the introduction of heavy atoms in the structure of these core of dyes seems to improve their phototherapeutic performance by increasing their singlet oxygen production ability [79], we aimed to study this variant in dyes analogous to those of our previous study. In general, although we have shown that the introduction of the iodine atom into the quinoline heterocycle did not increase its formation ability of this ROS, we found that this structural modification very significantly improved their in vitro phototherapeutic activity. Given the poor singlet oxygen production capacity of these dyes, such as those of their non-iodinated analogues, it can be inferred that the biological activity of these compounds mainly involves type I reactions, the mechanism by which ROS that cause a lesser extent of oxidative damage, such as superoxide anions and hydroxyl radicals, are produced. The comparison of the photodynamic activity of the dyes involved in the present study could also be rigorously made taking into account the results of the photostability assays since, besides presenting similar stability levels, they displayed a slight degradation to the irradiation times to which the cells were exposed.

\section{Conclusions}

In the presented work, a successful synthesis of unsymmetrical iodoquinoline- and benzothiazole-based squaraine dyes bearing amino and methylamino groups is described. All the synthesized dyes displayed narrow and intense absorption bands in the Vis/NIR region regardless of the polarity of the solvent used. Contrary to expectations, the singlet oxygen production quantum yields were similar to those obtained in non-iodinated dyes. Concerning to their photodegradation, the synthesized dyes, except for $O$-methylated precursor, showed moderate radiation stability. Interesting results were observed in the Alamar Blue cell proliferation assay in Caco-2 and HepG2 cells. The unsubstituted squaraine dye 
presented relevant in vitro phototherapeutic effects in both cell lines, as it exhibited low antiproliferative effects in the absence of irradiation $\left(\mathrm{IC}_{50}\right.$ values higher than or near the maximum tested concentration) and significantly lower half inhibitory concentrations when irradiated. Besides, the introduction of amine groups into the four-membered central ring increased the dark cytotoxicity of the dyes. However, it is noteworthy that the potentiality of these latter dyes is not invalidated since, compared to the dark, the half inhibitory concentration values in the light-presence are distinctly lower. In conclusion, compared to the non-iodinated dyes of our previous study, the inclusion of iodine atoms substantially improved the photobiological performance of these core of unsymmetrical dyes, so these latter bearing this heavy atom have so far intrinsic properties of a PDT photosensitizer candidate.

Supplementary Materials: The following are available online at http://www.mdpi.com/2076-3417/9/24/5414/s1, Figure S1: ${ }^{1} \mathrm{H}-\mathrm{NMR}$ spectrum of dye $10\left(600 \mathrm{MHz}, \mathrm{CDCl}_{3}\right)$, Figure S2: ${ }^{13} \mathrm{C}-\mathrm{NMR}$ spectrum of dye $10(150.9 \mathrm{MHz}$, $\left.\mathrm{CDCl}_{3}\right)$, Figure S3: ${ }^{1} \mathrm{H}-\mathrm{NMR}$ spectrum of dye $11\left(600 \mathrm{MHz}, \mathrm{CDCl}_{3}\right)$, Figure S4: ${ }^{13} \mathrm{C}-\mathrm{NMR}$ spectrum of dye $11\left(150.9 \mathrm{MHz}, \mathrm{CDCl}_{3}\right)$, Figure S5: ${ }^{1} \mathrm{H}-\mathrm{NMR}$ spectrum of dye $12\left(600 \mathrm{MHz}\right.$, DMSO- $\left.d_{6}\right)$, Figure S6: ${ }^{1} \mathrm{H}-\mathrm{NMR}$ spectrum of dye $12\left(600 \mathrm{MHz}\right.$, DMSO- $\left.d_{6}+\mathrm{D}_{2} \mathrm{O}\right)$, Figure S7: ${ }^{13} \mathrm{C}-\mathrm{NMR}$ spectrum of dye 12 (150.9 MHz, DMSO- $d_{6}$ ), Figure S8: ${ }^{1} \mathrm{H}-\mathrm{NMR}$ spectrum of dye $13\left(400 \mathrm{MHz}\right.$, DMSO- $\left.d_{6}\right)$, Figure S9: ${ }^{1} \mathrm{H}-\mathrm{NMR}$ spectrum of dye 13 (400 MHz, DMSO- $\left.d_{6}+\mathrm{D}_{2} \mathrm{O}\right)$, Figure S10: ${ }^{13} \mathrm{C}-\mathrm{NMR}$ spectrum of dye 13 (150.9 MHz, DMSO- $\left.d_{6}\right)$.

Author Contributions: Conceptualization, L.V.R. and A.M.S.; Investigation, S.F., E.L., R.E.B., D.F., J.R.F. and L.F.V.F.; Supervision, L.V.R. and A.M.S.; Writing-original draft, E.L.; Writing-review \& editing, R.E.B., L.F.V.F., A.M.S. and L.V.R.

Funding: This research was funded by the European Investment Funds by FEDER/COMPETE/POCI under projects POCI-01-0145-FEDER-006958 (CITAB) and POCI-01-0145-FEDER-007491 (CICS-UBI) and Funds by FCT - Portuguese Foundation for Science and technology, under the projects UID/AGR/04033/2019 (CITAB) and UID/QUI/UI0616/2019 (CQ-VR). This work was also supported by funds from the Health Sciences Research Center (CICS-UBI) through National Funds by FCT-Foundation for Science and Technology (UID/Multi/00709/2019). The research at CQFM was supported by Project UID/NAN/50024/2019 and M-ERA-NET/0002/2015 from FCT.

Conflicts of Interest: The authors declare no conflict of interest.

\section{References}

1. Cohen, S.; Lacher, J.R.; Park, J.D. Diketocyclobutenediol. J. Am. Chem. Soc. 1959, 81, 3480. [CrossRef]

2. Hollander, F.J.; Semmingsen, D.; Koetzle, T.F. The molecular and crystal structure of squaric acid (3,4-dihydroxy-3-cyclobutene-1,2-dione) at $121{ }^{\circ} \mathrm{C}$ : A neutron diffraction study. J. Chem. Phys. 1977, 67, 4825-4831. [CrossRef]

3. Ito, M.; West, R. New Aromatic Anions. IV. Vibrational Spectra and Force Constants for $\mathrm{C}_{4} \mathrm{O}_{4}{ }^{-2}$ and $\mathrm{C}_{5} \mathrm{O}_{5}{ }^{-2}$. J. Am. Chem. Soc. 1963, 85, 2580-2584. [CrossRef]

4. Reis, L.V.; Serrano, J.P.; Almeida, P.; Santos, P.F. New Synthetic Approach to Aminosquarylium Cyanine Dyes. Synlett 2002, 2002, 1617-1620.

5. Reis, L.; Serrano, J.; Almeida, P.; Santos, P. The synthesis and characterization of novel, aza-substituted squarylium cyanine dyes. Dyes Pigment. 2009, 81, 197-202. [CrossRef]

6. Bricks, J.L.; Kachkovskii, A.D.; Slominskii, Y.L.; Gerasov, A.O.; Popov, S.V. Molecular design of near infrared polymethine dyes: A review. Dyes Pigment. 2015, 121, 238-255. [CrossRef]

7. Xia, G.; Wang, H. Squaraine dyes: The hierarchical synthesis and its application in optical detection. J. Photochem. Photobiol. C Photochem. Rev. 2017, 31, 84-113. [CrossRef]

8. Avirah, R.R.; Jayaram, D.T.; Adarsh, N.; Ramaiah, D. Squaraine dyes in PDT: From basic design to In Vivo demonstration. Org. Biomol. Chem. 2012, 10, 911-920. [CrossRef]

9. Ramaiah, D.; Joy, A.; Chandrasekhar, N.; Eldho, N.V.; Das, S.; George, M.V. Halogenated Squaraine Dyes as Potential Photochemotherapeutic Agents. Synthesis and Study of Photophysical Properties and Quantum Efficiencies of Singlet Oxygen Generation. Photochem. Photobiol. 1997, 65, 783-790. [CrossRef]

10. Treibs, A.; Jacob, K. Cyclotrimethine Dyes Derived from Squaric Acid. Angew. Chem. Int. Ed. Engl. 1965, 4, 694. [CrossRef]

11. Fan, B.; Maniglio, Y.; Simeunovic, M.; Kuster, S.; Geiger, T.; Hany, R.; Nüesch, F. Squaraine Planar-Heterojunction Solar Cells. Int. J. Photoenergy 2009, 2009, 1-7. [CrossRef] 
12. Park, J.; Viscardi, G.; Barolo, C.; Barbero, N. Near-infrared Sensitization in Dye-sensitized Solar Cells. CHIMIA Int. J. Chem. 2013, 67, 129-135. [CrossRef]

13. Law, K.; Bailey, F.C. Squaraine chemistry. Synthesis and characterization of squaraine dyes having self-organizing properties. Dyes Pigment. 1992, 20, 25-40. [CrossRef]

14. Law, K.Y. Organic photoconductive materials: Recent trends and developments. Chem. Rev. 1993, 93, 449-486. [CrossRef]

15. Matsui, M.; Haishima, Y.; Kubota, Y.; Funabiki, K.; Jin, J.; Kim, T.H.; Manseki, K. Application of benz [c,d] indolenine-based unsymmetrical squaraine dyes to near-infrared dye-sensitized solar cells. Dyes Pigment. 2017, 141, 457-462. [CrossRef]

16. Zhu, Y.; Liu, J.; Zhao, J.; Li, Y.; Qiao, B.; Song, D.; Huang, Y.; Xu, Z.; Zhao, S.; Xu, X. Improving the Charge Carrier Transport and Suppressing Recombination of Soluble Squaraine-Based Solar Cells via Parallel-Like Structure. Materials 2018, 11, 759. [CrossRef]

17. Liu, T.; Yang, L.; Zhang, J.; Liu, K.; Ding, L.; Peng, H.; Belfield, K.D.; Fang, Y. Squaraine-hydrazine adducts for fast and colorimetric detection of aldehydes in aqueous media. Sens. Actuators B Chem. 2019, 292, 88-93. [CrossRef]

18. Lee, S.; Rao, B.A.; Son, Y.A. A highly selective fluorescent chemosensor for $\mathrm{Hg}^{2+}$ based on a squaraine-bis(rhodamine-B) derivative: Part II. Sens. Actuators B Chem. 2015, 210, 519-532. [CrossRef]

19. Basheer, M.C.; Alex, S.; George Thomas, K.; Suresh, C.H.; Das, S. A squaraine-based chemosensor for $\mathrm{Hg}^{2+}$ and $\mathrm{Pb}^{2+}$. Tetrahedron 2006, 62, 605-610. [CrossRef]

20. Ananda Rao, B.; Kim, H.; Son, Y.A. Synthesis of near-infrared absorbing pyrylium-squaraine dye for selective detection of $\mathrm{Hg}^{2+}$. Sens. Actuators B Chem. 2013, 188, 847-856. [CrossRef]

21. Jin, B.; Zhang, X.; Zheng, W.; Liu, X.; Zhou, J.; Zhang, N.; Wang, F.; Shangguan, D. Dicyanomethylene-Functionalized Squaraine as a Highly Selective Probe for Parallel G-Quadruplexes. Anal. Chem. 2014, 86, 7063-7070. [CrossRef]

22. Martins, T.D.; Pacheco, M.L.; Boto, R.E.; Almeida, P.; Farinha, J.P.S.; Reis, L.V. Synthesis, characterization and protein-association of dicyanomethylene squaraine dyes. Dyes Pigment. 2017, 147, 120-129. [CrossRef]

23. Volkova, K.D.; Kovalska, V.B.; Losytskyy, M.Y.; Reis, L.V.; Santos, P.F.; Almeida, P.; Lynch, D.E.; Yarmoluk, S.M. Aza-substituted squaraines for the fluorescent detection of albumins. Dyes Pigment. 2011, 90, 41-47. [CrossRef]

24. Lima, E.; Ferreira, O.; Gomes, V.S.D.; Santos, A.O.; Boto, R.E.; Fernandes, J.R.; Almeida, P.; Silvestre, S.M.; Reis, L.V. Synthesis and In Vitro evaluation of the antitumoral phototherapeutic potential of squaraine cyanine dyes derived from indolenine. Dyes Pigment. 2019, 167, 98-108. [CrossRef]

25. Friães, S.; Silva, A.M.; Boto, R.E.; Ferreira, D.; Fernandes, J.R.; Souto, E.B.; Almeida, P.; Ferreira, L.F.V.; Reis, L.V. Synthesis, spectroscopic characterization and biological evaluation of unsymmetrical aminosquarylium cyanine dyes. Bioorg. Med. Chem. 2017, 25, 3803-3814. [CrossRef]

26. Jemal, A.; Bray, F.; Center, M.M.; Ferlay, J.; Ward, E.; Forman, D. Global cancer statistics. CA Cancer J. Clin. 2011, 61, 69-90. [CrossRef]

27. Parsa, N. Environmental factors inducing human cancers. Iran. J. Public Health 2012, 41, 1-9.

28. Gilliam, L.A.A.; St. Clair, D.K. Chemotherapy-Induced Weakness and Fatigue in Skeletal Muscle: The Role of Oxidative Stress. Antioxid. Redox Signaling 2011, 15, 2543-2563. [CrossRef]

29. Severino, P.; De Hollanda, L.M.; Santini, A.; Reis, L.V.; Souto, S.B.; Souto, E.B.; Silva, A.M. Advances in nanobiomaterials for oncology nanomedicine. In Nanobiomaterials in Cancer Therapy; Elsevier: Amsterdam, The Netherlands, 2016; pp. 91-115. ISBN 978-0-323-42863-7.

30. Agostinis, P.; Berg, K.; Cengel, K.A.; Foster, T.H.; Girotti, A.W.; Gollnick, S.O.; Hahn, S.M.; Hamblin, M.R.; Juzeniene, A.; Kessel, D.; et al. Photodynamic therapy of cancer: An update. CA Cancer J. Clin. 2011, 61, 250-281. [CrossRef]

31. Buytaert, E.; Dewaele, M.; Agostinis, P. Molecular effectors of multiple cell death pathways initiated by photodynamic therapy. Biochim. Biophys. Acta (BBA) Rev. Cancer 2007, 1776, 86-107. [CrossRef]

32. Baskaran, R.; Lee, J.; Yang, S.G. Clinical development of photodynamic agents and therapeutic applications. Biomater. Res. 2018, 22, 25. [CrossRef] [PubMed]

33. Dos Santos, A.F.; De Almeida, D.R.Q.; Terra, L.F.; Baptista, M.S.; Labriola, L. Photodynamic therapy in cancer treatment-An update review. JCMT 2019, 5, 1-20. [CrossRef]

34. Nguyen, K.; Khachemoune, A. An update on topical photodynamic therapy for clinical dermatologists. J. Dermatol. Treat. 2019, 30, 732-744. [CrossRef] [PubMed] 
35. Blasi, M.A.; Pagliara, M.M.; Lanza, A.; Sammarco, M.G.; Caputo, C.G.; Grimaldi, G.; Scupola, A. Photodynamic Therapy in Ocular Oncology. Biomedicines 2018, 6, 17. [CrossRef]

36. Choi, Y.M.; Adelzadeh, L.; Wu, J.J. Photodynamic therapy for psoriasis. J. Dermatol. Treat. 2015, 26, $202-207$. [CrossRef]

37. Silva, A.M.; Siopa, J.R.; Martins-Gomes, C.; Teixeira, M.C.; Santos, D.J.; Dos Anjos Pires, M.; Andreani, T. New strategies for the treatment of autoimmune diseases using nanotechnologies. In Emerging Nanotechnologies in Immunology; Elsevier: Amsterdam, The Netherlands, 2018; pp. 135-163. ISBN 978-0-323-40016-9.

38. Hatz, K.; Schneider, U.; Henrich, P.B.; Braun, B.; Sacu, S.; Prünte, C. Ranibizumab plus Verteporfin Photodynamic Therapy in Neovascular Age-Related Macular Degeneration: 12 Months of Retreatment and Vision Outcomes from a Randomized Study. Ophthalmologica 2014, 233, 66-73. [CrossRef]

39. Ethirajan, M.; Chen, Y.; Joshi, P.; Pandey, R.K. The role of porphyrin chemistry in tumor imaging and photodynamic therapy. Chem. Soc. Rev. 2011, 40, 340-362. [CrossRef]

40. Ciubini, B.; Visentin, S.; Serpe, L.; Canaparo, R.; Fin, A.; Barbero, N. Design and synthesis of symmetrical pentamethine cyanine dyes as NIR photosensitizers for PDT. Dyes Pigment. 2019, 160, 806-813. [CrossRef]

41. Shen, Y.J.; Cao, J.; Sun, F.; Cai, X.L.; Li, M.M.; Zheng, N.N.; Qu, C.Y.; Zhang, Y.; Shen, F.; Zhou, M.; et al. Effect of photodynamic therapy with (17R,18R)-2-(1-hexyloxyethyl)-2-devinyl chlorine E6 trisodium salt on pancreatic cancer cells In Vitro and In Vivo. WJG 2018, 24, 5246-5258. [CrossRef]

42. Mehraban, N.; Musich, P.; Freeman, H. Synthesis and Encapsulation of a New Zinc Phthalocyanine Photosensitizer into Polymeric Nanoparticles to Enhance Cell Uptake and Phototoxicity. Appl. Sci. 2019, 9, 401. [CrossRef]

43. Zhang, J.; Jiang, C.; Figueiró Longo, J.P.; Azevedo, R.B.; Zhang, H.; Muehlmann, L.A. An updated overview on the development of new photosensitizers for anticancer photodynamic therapy. Acta Pharm. Sin. B 2018, 8, 137-146. [CrossRef] [PubMed]

44. Amarego, W.L.F.; Perrin, D.D. Purification of Laboratory Chemicals, 4th ed.; Butterworth-Heinemann: Oxford, UK, 1996; ISBN 0-7506-3761-7.

45. Pardal, A.; Ramos, S.; Santos, P.; Reis, L.; Almeida, P. Synthesis and Spectroscopic Characterisation of N-Alkyl Quaternary Ammonium Salts Typical Precursors of Cyanines. Molecules 2002, 7, 320-330. [CrossRef]

46. Tatarets, A.; Fedyunyaeva, I.; Terpetschnig, E.; Patsenker, L. Synthesis of novel squaraine dyes and their intermediates. Dyes Pigment. 2005, 64, 125-134. [CrossRef]

47. Kim, S.; Mor, G.K.; Paulose, M.; Varghese, O.K.; Baik, C.; Grimes, C.A. Molecular Design of Near-IR Harvesting Unsymmetrical Squaraine Dyes. Langmuir 2010, 26, 13486-13492. [CrossRef]

48. Reynolds, K.; Young, D.; Loughlin, W. Limitations of the 'Two-Phase' Doebner-Miller Reaction for the Synthesis of Quinolines. Synthesis 2010, 2010, 3645-3648.

49. Pacheco, M.L.F.M.; Friães, S.F.P.; Boto, R.E.; Almeida, P.; Silva, A.M.; Reis, L.V. Synthesis of a Squarylium Cyanine Dye as Potential Photosensitizer for Photodynamic Therapy (PDT). In Comprehensive Organic Chemistry Experiments for the Laboratory Classroom; The Royal Society of Chemistry: London, UK, 2017; pp. 301-305. ISBN 978-1-84973-963-4.

50. Ferreira, D.P.; Conceição, D.S.; Calhelha, R.C.; Sousa, T.; Socoteanu, R.; Ferreira, I.C.F.R.; Vieira Ferreira, L.F. Porphyrin dye into biopolymeric chitosan films for localized photodynamic therapy of cancer. Carbohydr. Polym. 2016, 151, 160-171. [CrossRef]

51. Andreani, T.; Kiill, C.P.; de Souza, A.L.R.; Fangueiro, J.F.; Fernandes, L.; Doktorovová, S.; Santos, D.L.; Garcia, M.L.; Gremião, M.P.D.; Souto, E.B.; et al. Surface engineering of silica nanoparticles for oral insulin delivery: Characterization and cell toxicity studies. Colloids Surf. B Biointerfaces 2014, 123, 916-923. [CrossRef]

52. Severino, P.; Andreani, T.; Jäger, A.; Chaud, M.V.; Santana, M.H.A.; Silva, A.M.; Souto, E.B. Solid lipid nanoparticles for hydrophilic biotech drugs: Optimization and cell viability studies (Caco-2 \& HEPG-2 cell lines). Eur. J. Med. Chem. 2014, 81, 28-34.

53. Santos, P.F.; Reis, L.V.; Almeida, P.; Serrano, J.P.; Oliveira, A.S.; Vieira Ferreira, L.F. Efficiency of singlet oxygen generation of aminosquarylium cyanines. J. Photochem. Photobiol. A Chem. 2004, 163, 267-269. [CrossRef]

54. Serpe, L.; Ellena, S.; Barbero, N.; Foglietta, F.; Prandini, F.; Gallo, M.P.; Levi, R.; Barolo, C.; Canaparo, R.; Visentin, S. Squaraines bearing halogenated moieties as anticancer photosensitizers: Synthesis, characterization and biological evaluation. Eur. J. Med. Chem. 2016, 113, 187-197. [CrossRef]

55. Ferreira, D.P.; Conceição, D.S.; Ferreira, V.R.A.; Graça, V.C.; Santos, P.F.; Ferreira, L.F.V. Photochemical properties of squarylium cyanine dyes. Photochem. Photobiol. Sci. 2013, 12, 1948. [CrossRef] [PubMed] 
56. Magalhães, Á.F.; Graça, V.C.; Calhelha, R.C.; Ferreira, I.C.F.R.; Santos, P.F. Aminosquaraines as potential photodynamic agents: Synthesis and evaluation of In Vitro cytotoxicity. Bioorg. Med. Chem. Lett. 2017, 27, 4467-4470. [CrossRef] [PubMed]

57. Rapozzi, V.; Beverina, L.; Salice, P.; Pagani, G.A.; Camerin, M.; Xodo, L.E. Photooxidation and Phototoxicity of $\pi$-Extended Squaraines. J. Med. Chem. 2010, 53, 2188-2196. [CrossRef] [PubMed]

58. Santos, P.F.; Reis, L.V.; Almeida, P.; Oliveira, A.S.; Vieira Ferreira, L.F. Singlet oxygen generation ability of squarylium cyanine dyes. J. Photochem. Photobiol. A Chem. 2003, 160, 159-161. [CrossRef]

59. Leir, C.M. An improvement in the Doebner-Miller synthesis of quinaldines. J. Org. Chem. 1977, 42, 911-913. [CrossRef]

60. Lima, E.; Ferreira, O.; Silva, J.F.; Santos, A.O.; Boto, R.E.; Fernandes, J.R.; Almeida, P.; Silvestre, S.M.; Reis, L.V. Photodynamic activity of indolenine-based aminosquaraine cyanine dyes: Synthesis and In Vitro photobiological evaluation. Dyes Pigment. 2019, 108024. [CrossRef]

61. O'Connor, A.E.; Gallagher, W.M.; Byrne, A.T. Porphyrin and Nonporphyrin Photosensitizers in Oncology: Preclinical and Clinical Advances in Photodynamic Therapy. Photochem. Photobiol. 2009, 85, 1053-1074. [CrossRef]

62. Vankayala, R.; Hwang, K.C. Near-Infrared-Light-Activatable Nanomaterial-Mediated Phototheranostic Nanomedicines: An Emerging Paradigm for Cancer Treatment. Adv. Mater. 2018, 30, 1706320. [CrossRef]

63. Dabrowski, J.M.; Arnaut, L.G. Photodynamic therapy (PDT) of cancer: From local to systemic treatment. Photochem. Photobiol. Sci. 2015, 14, 1765-1780. [CrossRef]

64. van Straten, D.; Mashayekhi, V.; de Bruijn, H.; Oliveira, S.; Robinson, D. Oncologic Photodynamic Therapy: Basic Principles, Current Clinical Status and Future Directions. Cancers 2017, 9, 19. [CrossRef]

65. Paszko, E.; Ehrhardt, C.; Senge, M.O.; Kelleher, D.P.; Reynolds, J.V. Nanodrug applications in photodynamic therapy. Photodiagn. Photodyn. Ther. 2011, 8, 14-29. [CrossRef] [PubMed]

66. Krinsky, N.I. Singlet oxygen in biological systems. Trends Biochem. Sci. 1977, 2, 35-38. [CrossRef]

67. Baptista, M.S.; Cadet, J.; Di Mascio, P.; Ghogare, A.A.; Greer, A.; Hamblin, M.R.; Lorente, C.; Nunez, S.C.; Ribeiro, M.S.; Thomas, A.H.; et al. Type I and Type II Photosensitized Oxidation Reactions: Guidelines and Mechanistic Pathways. Photochem. Photobiol. 2017, 93, 912-919. [CrossRef] [PubMed]

68. Moan, J. Effect of bleaching of porphyrin sensitizers during photodynamic therapy. Cancer Lett. 1986, 33, 45-53. [CrossRef]

69. Yogo, T.; Urano, Y.; Ishitsuka, Y.; Maniwa, F.; Nagano, T. Highly Efficient and Photostable Photosensitizer Based on BODIPY Chromophore. J. Am. Chem. Soc. 2005, 127, 12162-12163. [CrossRef]

70. Ferreira, J.; Menezes, P.F.C.; Sibata, C.H.; Allison, R.R.; Zucoloto, S.; Castro e Silva, O.; Bagnato, V.S. Can efficiency of the photosensitizer be predicted by its photostability in solution? Laser Phys. 2009, 19, 1932-1938. [CrossRef]

71. Terpetschnig, E.; Szmacinski, H.; Lakowicz, J.R. An investigation of squaraines as a new class of fluorophores with long-wavelength excitation and emission. J. Fluoresc. 1993, 3, 153-155. [CrossRef]

72. Donato, M.T.; Tolosa, L.; Gómez-Lechón, M.J. Culture and Functional Characterization of Human Hepatoma HepG2 Cells. In Protocols in In Vitro Hepatocyte Research; Vinken, M., Rogiers, V., Eds.; Springer: New York, NY, USA, 2015; Volume 1250, pp. 77-93. ISBN 978-1-4939-2073-0.

73. Granados-Romero, J.J.; Valderrama-Treviño, A.I.; Contreras-Flores, E.H.; Barrera-Mera, B.; Herrera Enríquez, M.; Uriarte-Ruíz, K.; Ceballos-Villalba, J.C.; Estrada-Mata, A.G.; Alvarado Rodríguez, C.; Arauz-Peña, G. Colorectal cancer: A review. Int. J. Res. Med. Sci. 2017, 5, 4667. [CrossRef]

74. Chantret, I.; Barbat, A.; Dussaulx, E.; Brattain, M.G.; Zweibaum, A. Epithelial polarity, villin expression, and enterocytic differentiation of cultured human colon carcinoma cells: A survey of twenty cell lines. Cancer Res. 1988, 48, 1936-1942.

75. Hamid, R.; Rotshteyn, Y.; Rabadi, L.; Parikh, R.; Bullock, P. Comparison of alamar blue and MTT assays for high through-put screening. Toxicol. In Vitro 2004, 18, 703-710. [CrossRef]

76. International Standard (ISO). Biological Evaluation of Medical Devices. Part 5: Tests for In Vitro Cytotoxicity, 3rd ed.; ISO-10993-5; International Standard (ISO): Geneva, Switzerland, 2009.

77. Bácskay, I.; Nemes, D.; Fenyvesi, F.; Váradi, J.; Vasvári, G.; Fehér, P.; Vecsernyés, M.; Ujhelyi, Z. Role of Cytotoxicity Experiments in Pharmaceutical Development. In Cytotoxicity; Çelik, T.A., Ed.; InTech: London, UK, 2018; ISBN 978-1-78923-430-5. 
78. Meacham, C.E.; Morrison, S.J. Tumour heterogeneity and cancer cell plasticity. Nature 2013, 501, $328-337$. [CrossRef] [PubMed]

79. Santos, P.F.; Reis, L.V.; Duarte, I.; Serrano, J.P.; Almeida, P.; Oliveira, A.S.; Ferreira, L.F.V. Synthesis and Photochemical Evaluation of Iodinated Squarylium Cyanine Dyes. HCA 2005, 88, 1135-1143. [CrossRef] 